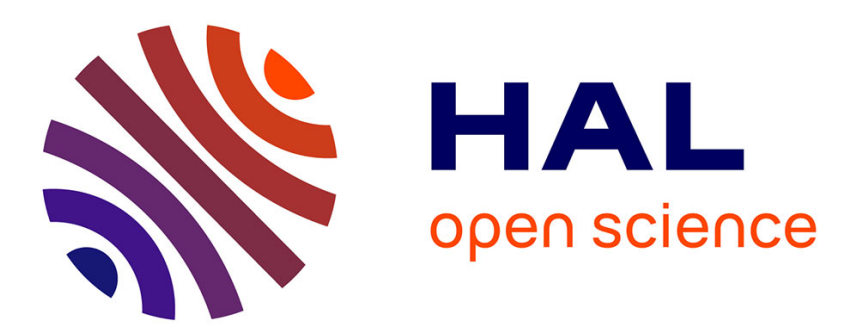

\title{
The Credit Default Swap market contagion during recent crises: International evidence
}

\author{
Saker Sabkha, Christian de Peretti, Dorra Hmaied
}

\section{To cite this version:}

Saker Sabkha, Christian de Peretti, Dorra Hmaied. The Credit Default Swap market contagion during recent crises: International evidence. Review of Quantitative Finance and Accounting, 2018. hal01572510

\section{HAL Id: hal-01572510 https://hal.science/hal-01572510}

Submitted on 7 Aug 2017

HAL is a multi-disciplinary open access archive for the deposit and dissemination of scientific research documents, whether they are published or not. The documents may come from teaching and research institutions in France or abroad, or from public or private research centers.
L'archive ouverte pluridisciplinaire HAL, est destinée au dépôt et à la diffusion de documents scientifiques de niveau recherche, publiés ou non, émanant des établissements d'enseignement et de recherche français ou étrangers, des laboratoires publics ou privés. 


\title{
The Credit Default Swap market contagion during recent crises: International evidence
}

\author{
Saker Sabkha ${ }^{1,2}$, Christian de Peretti ${ }^{1}$ and Dorra Hmaied ${ }^{2}$ \\ ${ }^{1}$ Univ Lyon, University Claude Bernard Lyon 1, Institute of Financial and Insur- \\ ance Sciences,LSAF-EA2429, F-69007, Lyon, France \\ ${ }^{2}$ Univ of Carthage, Institute of High Commercial Studies, LEFA, Tunis, Tunisia
}

\begin{abstract}
This paper analyzes the dynamics of credit default swaps spreads in order to determine whether the sovereign credit default swap market is prone to contagion effects. Analysis is made on credit default swap spreads data of 35 worldwide countries belonging to four different categories of economies over a period ranging from 2006 until 2014, covering the subprime crisis and the European sovereign debt crisis. A novel approach is proposed to estimate dynamic conditional correlations between CDS spreads using AR(1)-FIEGARCH(1,d,1)-DCC model. Based on our findings, we put a slant on the financial market vulnerability, reinforced by contagion effects during the different phases of the crises. Furthermore, analysis of each county solely show that contagion effects are more stern during the Eurozone crisis comparing to the global financial crisis and that the level of exposure to crises is different across global markets and regions. Yet, our approach provide evidences that crises spread to countries across the world regardless their economic status or geographical positions.
\end{abstract}

\section{Keywords}

Sovereign risk spillover; Credit Default Swaps; contagion phenomenon; dynamic conditional correlation. 


\section{Introduction}

Several episodes of financial crises occurred recursively since the globalization and the creation of the financial sphere. An accentuation of this recurring phenomenon was observed during the last two decades with the occurrence of more and more financial crises characterized not only by their persistence but especially by their severity and magnitude. Starting with the great depression of 1929 in the USA, other crises have followed such as the European Monetary System (EMS) crisis in 1992-1993, Latin American crisis in 1994, Asian financial crisis in 19971998, Russian crisis in 1998 and Brazilian crisis in 1999. The most recent crises are the tech bubble burst in the US in 2001, the subprime crisis of 2007 and the $\mathrm{Eu}-$ ropean Sovereign Debt Crisis of 2010 (Reinhart and Rogoff, 2008; D'Apice and Ferri, 2010; Reinhart, 2010). Besides the fact that crises are constantly emerging for years, it is crucial to note that their nature is constantly changing over time. Indeed, crises seem to last longer, since that 9 years after the 2007 crisis, the financial market continued to feel its effects (Dron and Pillet, 2016; Pentecôte, Poutineau, Rondeau et al., 2016). This is in addition to the development of a contagious nature throughout markets, whereby the occurrence of a crisis in a country can have effects on international financial markets and spreads to other countries. Financial researchers have always used the contagion word to talk about such effects.

In light of these observations, economists started to develop empirical models to anticipate crises and to study factors likely to accentuate this kind of phenomenon in order to understand if these crises constitute independent events or rather symptoms of contagion phenomena. The answer to this question is very important to understand the two recent crises: the credit crisis (2007-2009) and the European sovereign debt crisis (2010). Yet, it is very important to understand in which way shocks are spreading through countries so economists and policy makers can reduce the extend of instability and contagion effects. Studying financial contagion is also important for fund managers and investors so they can revise upward spillover risk and take into account the limits of portfolio diversification.

Since derivatives markets play an important role in the price discovery process of financial assets, we try in this paper to study contagion phenomenon in the credit derivatives market. Using a new class of model based on the AR(1)FIEGARCH-DDC, this paper aims to study contagion effects within the sovereign Credit Default Swap markets in order to investigate the vulnerability of these markets to such phenomenon. This question seems to be intriguing since during the recent financial crisis a common and joint increase in CDS spreads was observed. We study the dynamics of CDS markets during the two recent financial turmoil, namely the global financial crisis beginning with the collapse of the subprime market in 2007 and the European Sovereign Debt crisis. The ultimate 
goal is to verify whether there is a shock spillover across sovereign Credit Default Swap markets and to quantify markets interactions. To address this problematic, we analyze Credit Default Swap (CDS, hereafter) spreads dynamic conditional correlations between 35 countries - belonging to different different geographical regions (Eastern Europe, Western Europe, North America, South America and Asia) and economic levels (low economic growt countries, developed countries, newyly industrialized countries and emerging countries) so as to compose a representative sample of the international sovereign credit market- through the Exponentially-Weighted Moving Average (EWMA) model (Coudert and Gex, 2010; Kalbaska and Gatkowski, 2012) and the AR(1)-FIEGARCH(1,d,1)-DCC models (Christensen, Nielsen and Zhu, 2010). These approaches are used to determine the existence of significant links between different markets on different sub-periods and compare the strengths of responses of each country to contagion effects.

This paper contributes to the existence literature on several perspectives: First, we extend the field of study and go beyond the context abundantly studied: countries are chosen as to represent a benchmark of the international CDS markets and give thus some international evidences of sovereign contagion from a worldwide perspective rather than a local or regional point of view as it has been done in the literature. Second, contrary to other studies focusing on sovereign CDS markets, we examine both recent crises - namely the global financial crisis 2007-2009 (GFC, hereafter) and the European debt crisis - given that distress transmission depends on crises' magnitude ad severity. Third, approaches used in our paper are more accurate since they allow to take into account more CDS market properties (such as the long-memory range, information asymmetries..). Yet, we don't limit our investigation to country-by-country analysis. Indeed, contagion analysis on regional and economic level aggregate can be different across global markets and regions since the level of exposure to crises is different across global markets and regions.

Our results allows us to draw three major conclusions: Sovereign CDS market is prone to contagion effects especially during turmoil episodes. The level of exposure to crises is different across global markets and regions. And, crises spread to countries across the world regardless their economic status or geographical positions.

The rest of the paper is organized as follows: Section 2 gives necessary background information about financial contagion and related works. Section 3 and 4 are respectively dedicated to sample description and our proposed methodology for contagion detection among sovereign credit default swaps markets. Empirical results are covered in section 5. Section 6 depicts an economic discussion and section 7 concludes the paper and outlines possible economic and financial implications. 


\section{Crises and contagion : Literature review}

\subsection{Contagion definition}

The identification, measurement and prediction of the contagion phenomena depend on the definition of this concept. The term contagion remains controversial and has always stirred widespread discord among economists as to its exact definition and measure. Indeed, whether theoretically or empirically speaking, too many ambiguities arise as to the exact definition of contagion and no method for quantifying it wins unanimous support of researchers. However, by taking stock of previous studies, we find a summary definition that is commonly used in the theoretical literature and its corresponding measure adopted in empirical works. Generally, contagion is defined as a transmission of financial shocks through countries. It corresponds to a scenario in which financial shocks, affecting at first only a few financial institutions or some parts of the economy, spread to the rest of the financial sector and other countries of the global economy resulting in a simultaneous increase in assets prices' co-movements (Kalbaska and Gatkowski, 2012) ${ }^{1}$.

A first category of researchers think that there are some reasons related to countries idiosyncratic features (trade linkages and free-trade area, financial agreements and cooperations, markets' characteristics ... ) that make them vulnerable to contagion effects(Forbes and Chinn, 2004; Borio, 2008). Another strand of the literature defines this phenomenon as pure contagion that cannot be explained by any changes in fundamentals of countries (Pericoli and Sbracia, 2003; Caporale, Cipollini and Spagnolo, 2005). Pure contagion occurs when a significant increase in correlations between financial markets is due to a shock relative to a change in investors' appetite towards risk: when risk aversion of investors increases, they reduce their exposure to risky assets resulting in a fall in these assets' prices. Contrarly, when the risk appetite of the investors increases, they increase their demand for risky assets which increases their values simultaneously (Forbes and Rigobon, 2002; Coudert and Gex, 2010; Broto and Perez-Quiros, 2015). Thus, the pure contagion operates in the same direction as the level of risk aversion and is in no way related to fundamentals, exchange regime or country exchange rates (Kumar and Persaud, 2002). This paper only focuses on pure contagion phenomenon between crises generators (USA, Greece and Ireland) and 34 countries

\footnotetext{
${ }^{1}$ For a complete survey on different contagion definitions, see Missio and Watzka (2011) whom summarize all the existing definitions in the literature and draw up a report of the five most used ones: (i) There is a financial contagion when the probability of crisis in one country increases considerably after the occurrence of a crisis in another country; (ii) Contagion phenomenon is observed when there is a simultaneous rise of several financial assets volatilities across markets of one country; (iii) Contagion is defined as a sudden modification of financial assets prices without any economic explanations related to fundamentals and (iiiii) the significant increase in prices co-movements across international markets implies a contagion phenomenon.
} 
from all over the world.

\subsection{Related works}

The state of the art of financial contagion phenomenon can be divided into three groups following the study aim: First, empirical studies list several transmission channels of financial distress that may explain contagion in financial markets. Several researchers investigate on pathways through which crises can be transmitted and highlight different factors that could make a market prone to contagion effects. By taking stock of this literature, a summary four transmission channels can be drawn: the correlated information channel also known as the wake-up call hypothesis, the liquidity channel, the cross-market hedging channel and the counterparty risk (Pritsker, 2001; Chiang, Jeon and Li, 2007; Kodres and Pritsker, 2002). Extensive studies on the last channel exist whether theoretical or empirical. Jarrow and Yu (2001) develop a theoretical model including default probabilities of counterparty in order to explain the negative impact of defaulter companies on the whole economy observed during the crises of Asia in 1997. Results show that default probabilities of financial companies are correlated and that they do not depend only on common risk factors but they also depend on specific factor called counterparty risk. An empirical measurement of this counterparty risk was integrated in pricing models of bonds and credit derivatives (Blinder, 2013; Markose, Giansante, Gatkowski and Shaghaghi, 2010; Jorion and Zhang, 2007; Packer and Wooldridge, 2005).

Second, Alter and Schüler (2012) examine the co-movement relationship between sovereign CDS of seven European countries (France, Germany, Italy, Ireland, Netherlands, Portugal and Spain) and the corresponding CDS of their domestic banks from 2007 to 2010 . Using cointegration analysis, Granger causality and Impulse Responses Functions ${ }^{2}$, Alter and Schüler (2012) show that rescue operations, engaged by the International Monetary Fund and the European Union, have an impact on the relationship between the two CDS markets. They note that for the period preceding the governments interventions, banks' CDS exert a contagion effect on sovereign CDS, while during the second period, sovereign CDS market takes the lead. This relationship direction is only valid and significant in the short-term. In the same context, Acharya, Drechsler and Schnabl (2014) find empirical evidences of a direct feedback relationship between sovereign CDS market and the private sector (Banks' CDS). Wang and Moore (2012) also show that the financial distress of Lehman Brothers spread to the sovereign markets. In the same context, several economists have focused on interdependence between

\footnotetext{
${ }^{2}$ The impulse response function (IRF) gives informations about the present and future evolution (extent and duration) of a time series, following a financial shock on an innovation.
} 
the 2007 credit crisis and the European sovereign debt crisis (de Castro Miranda, Tabak, Junior et al., 2012; Ejsing and Lemke, 2011; Acharya et al., 2014). Results of these studies point to the fact that the implementation of bank bailout programs by the European government lead to an increase in the sovereign credit risk because of the generated costs. The several rescue operations induce a degradation of governments' balance sheets and guarantees and cause, thus, a spread of crisis from the private sector to public finances. Moreover, the authors show that these financial rescue packages cost leads to the increase of the sensitivity of government credit risk to possible financial shocks.

Third, a large body of the literature concentrates on the study of contagion existence in financial markets. Indeed, many researchers reconsider the financial crisis of 2007 in order to understand the reaction of the whole CDS market regarding turmoil phases. Using an EWMA model, empirical evidences of contagion phenomenon occurrence are found on the USA and the European CDS markets following the financial distress of General Motors and Ford in March 2005 (Packer and Wooldridge, 2005; Coudert and Gex, 2010). Financial trouble of these two firms has effects on the credit market because of their enormous issued amounts of debts. This contagion phenomenon is reinforced with the fact that a great number of Collateralized Debt Obligations (CDO) have for collateral the debts of these two companies. Similarly, by using the standard event study, Jorion and Zhang (2007) empirically examine the effect of a credit event (bankruptcy) on the information transfer between companies. The principal drawn conclusions are that a positive correlation between the CDS spreads of several companies implies a contagion effect, whereas a negative correlation supposes the predominance of competition effects. Yet, the study of financial contagion during the European debt crisis is still expanding. Grammatikos and Vermeulen (2012) show that the European sovereign CDS market is subject to a contagion effect caused mainly by the inability of Greece to repay its debts. Through an EWMA framework analysis, Kalbaska and Gatkowski (2012) provide evidence of financial contagion occurrence in sovereign CDS markets (PIIGS ${ }^{3}$, UK, France and Germany) based on a data spanning from 2005 to 2010 covering the GFC. Our paper contribution is build up upon this last strand of the literature.

\subsection{Limits of the literature}

Most of these previous studies focus on homogeneous samples by studying contagion between countries that are either connected by their economies or by their geographical positions. Indeed, all research based on crises' transmission be-

\footnotetext{
${ }^{3}$ Portugal, Ireland, Italy, Greece and Spain.
} 
tween the PIIGS ${ }^{4}$ - for example - are somewhat predictable and obvious since these countries are financially very unstable making them logically very vulnerable to financial distress; and are commercially closely linked which is undoubtedly a transmission channel of the financial turmoil (Pan and Singleton, 2008; Longstaff, Pan, Pedersen and Singleton, 2011). However, studies that focus especially on international dataset are infrequent. Caramazza, Ricci and Salgado (2004) study the Mexican, Asian and Russian crises' spread to the entire world, during the 1990's. Using an error correction model, Srivastava, Lin, Premachandra and Roberts (2016) give evidence of risk spillover from the equity market to the sovereign CDS markets of 56 studied sovereigns (See Lee, Paek, Ha and Ko (2015) for a similar study). Our empirical analysis allows us to give an international evidence of crises' spread over sovereign CDS markets, which is quite important given the international diversification of portfolio investment and since the world is moving towards a single economic and financial policy.

Indeed, our sample is composed by a reference pool (PIIGS), i.e. countries with low economic growth, around which we chose to study countries that are uncorrelated economically and/or geographically. First, if contagion spreads from one country to another, countries' geographical diversification seems to be very interesting. Second, it is important to test contagion effects on countries in which crises are likely to have a quite different impact ${ }^{5}$ : developed countries, newly industrialized countries ${ }^{6}$ and emerging countries $\left.{ }^{7}\right)^{8}$.

On the other hand, many of these works are based on the adjusted correlation coefficients which are none other than the corrected unconditional Pearson correlation coefficients. Several critics have been developed against the use of this method saying that the results only inform us about the degree of correlation of each sub-period without considering the underlying dynamic between the different sub-periods. Furthermore, another disadvantage of this method is that the tests are only performed with latest information. It thus avoids information of the series patterns contained in the latest estimations. This technique there-

\footnotetext{
${ }^{4}$ PIIGS are the 5 European countries that suffer the most from indebtedness and represent a low growth perspectives with high unemployment rates. They are called, somewhat disdainfully, 'Club Med' countries for their fiscal laxity and the fragility of their economies.

${ }^{5}$ Some empirical studies show that developed countries are more likely to constitute a transmission channel of crisis and suggest that reasons of the propagation of turmoil in industrial countries differ from those in emerging countries (Caramazza et al., 2004).

${ }^{6}$ These are all economies which, by their development strategies, have experienced a major industrial take-off over the last 20 to 40 years.

${ }^{7}$ These countries are characterized by a fast economic growth but still have not reach the level of GDP per capital of developed countries. Unlike the newly industrialized countries, emerging countries have already had a significant industrial sector or develop in sectors other than industry.

${ }^{8}$ We use different criteria of countries' economic classification (the NU, the CIA World Factbook, the IMF and the World Bank criteria) as to have a sample of sufficient size in each category.
} 
fore proves to be inefficient for detecting low correlations. Unlike these studies, our work is based on a time varying dynamic conditional correlations (EWMA and AR(1)-FIEGARCH-DCC) letting us make a common interest into past and present observations and to take in account CDS market's specifications (volatility clustering, information asymmetry, long-memory behavior...).

\section{Sample description}

This section presents our paper contribution: The sample used is composed by countries all over the world allowing us to give international evidences of global financial contagion on sovereign CDS markets.

\subsection{Data and sample description}

The sample studied is composed by sovereign CDS issued on the bonds of 35 countries with different economic status (low economic growth, developed countries, newly industrialized countries and emerging countries) and belonging to four different geographical regions (Eastern Europe, South and Central America, Asia and Western Europe) (See Table 1). The interest of the choice of these countries relies on the fact that uncorrelated worldwide economies are chosen in such a way as to be able to study the international context. For each country, 5-year daily CDS spreads denominated in $\mathrm{USD}^{9}$ and expressed in Basis points are used. Data is gathered from Thomson Reuters $\cap$ and Bloomberg $\cap$. In order to improve CDS spreads' reliability and keep a high-quality database, we first extract observed CDS contracts following aforementioned criteria, which represent the major part of our sample dataset. Then, we fill the gaps with contracts denominated in another currency and/or other maturities.

The data collected extends from January $2^{\text {nd }}$, 2006 until April $3^{\text {rd }}$, 2014, leading to a sample size of 2154 observations per series. Before 2006, the Sovereign CDS market was relatively illiquid, especially for developed countries, that's why our analysis begins from that date. Almost all data series for our chosen countries are available for the full studied period, except for Greece where data covers only until September $12^{\text {th }}, 2013$ when its credit market became completely illiquid. Our sample period covers the global financial crisis as well as the Sovereign Debt crisis.

\footnotetext{
${ }^{9}$ Although CDS contracts exist for other maturities(1-year, 2-year, 3-year, 4-year, 10-year...) and other currencies (EUR, JPY, pound sterling...). Our sample is only limited to the 5-year maturity and the US denomination because it's the most liquid market segment.
} 
Table 1: Countries classifications according to their economic status and geographical positions

\begin{tabular}{|c|c|c|}
\hline Economy & Country & Continent \\
\hline $\begin{array}{c}\text { PIIGS_low economic growth } \\
\text { countries (5) }\end{array}$ & $\begin{array}{l}\text { Portugal } \\
\text { Ireland } \\
\text { Italy } \\
\text { Greece } \\
\text { Spain }\end{array}$ & $\begin{array}{l}\text { Western Europe } \\
\text { Western Europe } \\
\text { Western Europe } \\
\text { Western Europe } \\
\text { Western Europe }\end{array}$ \\
\hline Developed countries (17) & $\begin{array}{l}\text { Austria } \\
\text { Belgium } \\
\text { Denmark } \\
\text { Estonia } \\
\text { Finland } \\
\text { France } \\
\text { Germany } \\
\text { Japan } \\
\text { Latvia } \\
\text { Lithuania } \\
\text { Netherlands } \\
\text { Norway } \\
\text { Slovakia } \\
\text { Slovenia } \\
\text { Sweden } \\
\text { UK } \\
\text { USA } \\
\end{array}$ & $\begin{array}{l}\text { Western Europe } \\
\text { Western Europe } \\
\text { Western Europe } \\
\text { Eastern Europe } \\
\text { Western Europe } \\
\text { Western Europe } \\
\text { Western Europe } \\
\text { Asia } \\
\text { Eastern Europe } \\
\text { Eastern Europe } \\
\text { Western Europe } \\
\text { Western Europe } \\
\text { Eastern Europe } \\
\text { Eastern Europe } \\
\text { Western Europe } \\
\text { Western Europe } \\
\text { North America }\end{array}$ \\
\hline Newly industrialized countries (4) & $\begin{array}{l}\text { Brazil } \\
\text { China } \\
\text { Qatar } \\
\text { Turkey }\end{array}$ & $\begin{array}{l}\text { South America } \\
\text { Asia } \\
\text { Asia } \\
\text { Asia }\end{array}$ \\
\hline Emerging countries (9) & $\begin{array}{l}\text { Bulgaria } \\
\text { Croatia } \\
\text { Czech } \\
\text { Hungary } \\
\text { Poland } \\
\text { Romania } \\
\text { Russia } \\
\text { Ukraine } \\
\text { Venezuela } \\
\end{array}$ & $\begin{array}{l}\text { Eastern Europe } \\
\text { Eastern Europe } \\
\text { Eastern Europe } \\
\text { Western Europe } \\
\text { Eastern Europe } \\
\text { Eastern Europe } \\
\text { Asia } \\
\text { Eastern Europe } \\
\text { South America }\end{array}$ \\
\hline
\end{tabular}

The classification of these 35 countries is made according to the NU, the

CIA World Factbook, the IMF and the World Bank criteria. 


\subsection{Crisis timeline}

Previous researches define the length, the breadth and the crises' chronology using whether an economic approach or econometric approach. On the one hand, studies determining crises' timeline based on economic and financial events, such as Kalbaska and Gatkowski (2012), seems to be arbitrary in a certain way since the definition and the location of crises in time are chosen subjectively. On the other hand, the statistical approach may also presents some flexibility problems since it avoids relating the crises period identification with economic events (Kenourgios and Dimitriou, 2015). In order to determine correctly the crises' chronology, we use a methodology taking into account both economic and econometric approaches following (Dimitriou, Kenourgios and Simos, 2013). Dimitriou et al. (2013) have only used this technique to define the recent international credit crisis while we use it to determine the GFC as well as the European debt crisis.

We start by defining a relatively long period covering both the international financial crisis and the European debt crisis. Given the interdependence and the coupling between this two crises, it seems interesting to study the CDS market behavior during those different turmoil phases in order to distinguish between markets' reactions to different crises'. Among several studies, we choose to refer to the official timeline provided by the BIS $(2009)^{10}$ to define different phases of the GFC: (i) A pre-crisis period where the world banking system were somehow healthy, strengthened and sound coupled by a generally favorable economic conditions. This period is called a "tranquil period" and is prior to the third quarter of 2007. (ii) A $1^{\text {st }}$ crisis period characterized by an increase in the inability of market's actors to correctly price some risky structured credit products (namely the subprimes). This phase is known as the "Initial financial turmoil" and it spans from July 2007 to mid-September 2008. It has been triggered by the start of Bear Sterns' problems and by the BNP Paribas's announcement of the financial crisis and the credit crunch. (iii) A $2^{\text {nd }}$ turmoil phase is defined by the BIS as a "Sharp financial market deterioration" starting up from mid-September 2008 until late 2008. At this stage of the financial crisis, the whole world's perspectives have sharply changed (abruptly decrease in risk appetites with big loss of market confidence) due to Lehman Brothers Bankruptcy ${ }^{11}$. The $3^{\text {rd }}$ crisis phase is defined as a "Macroeconomic deterioration" because of the role played by the drastic policy measures in calming financial system, stabilizing markets and decreasing counterparty risk. It spans from late 2008 until the end of the first quarter of 2009.The last phase described by the BIS (2009) is called "Stabilization and tentative signs

\footnotetext{
${ }^{10}$ See also the Federal Reserve Bank of ST. Louis's report entitled "The Financial crisis: a time-line of events and policy actions" (2009).

${ }^{11}$ Lehman Brothers, the $4^{\text {th }}$ biggest investment bank in U.S.A., has been declared Bankrupt in September $15^{\text {th }}, 2008$.
} 
of recovery" (from Q2 2009 - October 2009) during which some hope signs appeared, financial indicator came back to normal thresholds and investors re-adjust upwards their risk appetite.

By referring to Thomson Reutherss official publications the European debt crisis goes through 4 phases: (i) From October 2009 until April 2010, "The Greeces accounting unravels" phase where the world has figured out that the Greeces budget deficit is much more higher than what the country has announced. (ii) The $2^{\text {nd }}$ phase started after the adoption of EU-IMF bailout measures following the increase of the sovereign credit risk. This phase is called "The crisis spread" and spans from May 2010 until June 2011. (iii) From July 2011 to March 2012, the Crisis deepens and the sovereign risk increases to new high levels since the Euroarea finance ministers put off any decision on the sovereign debt program. (iiii) From April 2012 onwards, the Euro area is living a phase of "Containing the crisis" whith the adoption of a permanent rescue fund whose role is to get countries and banks' balance sheets under control (for a more detailed sovereign debt crisis timeline see the survey of Pisani-Ferry, Sapir, Wolff et al. (2013) entitled "EUIMF assistance to Eurozone countries: an early assessment"). Thus, the European debt crisis could be defined from August 2007 until March 2009 and the Debt crisis could be defined from October 2009 until March 2012.

Next, since financial crisis are characterized by an increase in financial assets' volatilities, we check for phases of excess volatility for each of the CDS markets using the Markov switching ARMA model. As explained by Dimitriou et al. (2013), this class of models takes into account structural breaks (two regimes stable and volatile where 0 means that values of the conditional volatilities are low and 1 means that values of the conditional volatilities are high) and thus allows us to define different sub-periods of the crisis. Results of the filtered regime probabilities are presented in Fig. 1.

By taking stock of the results of these two previous methods, the studied period can be divided into 4 sub-periods:

- From January, 2006 to June, 2007: a reference period (tranquil period);

- From July, 2007 to March, 2009: $1^{\text {st }}$ crisis period (credit crunch);

- From March, 2009 to October, 2009: Post- crisis period (tranquil period);

- From November, 2009 to March, 2012: $2^{\text {nd }}$ crisis period (European Debt crisis);

- From March, 2012 to April, 2014: Post- crisis period (tranquil period); 


\section{Methodology: A Dynamic Conditional Correla- tion approach}

As mentioned before, in order to investigate the existence of pure contagion on the sovereign CDS market, we rely on the contagion detection method suggested by Pericoli and Sbracia (2003) and Caporale et al. (2005): contagion is defined as a significant increase in the degree of co-movement between countries during crisis compared to normal periods. We start thus our econometric analysis by estimating conditional correlations between CDS spreads of crisis sources (USA, Greece and/or Ireland) and the remaining 34 countries of the sample. To do so, two econometric approaches are presented in the next subsections in order to estimate dynamic conditional correlations: a referenced method based on an EWMA model - used to compare our findings with the previous literature results - and a more complex method that has a high computational complexity based on an AR(1)-FIEGARCH(1,d,1)-DCC model.

Since most of financial times series are modeled by an autoregressive process (Goudarzi and Ramanarayanan, 2010; Conrad, Karanasos and Zeng, 2011) and because of the markets' efficiency, the mean equation of the time series is assumed to be generated by an 

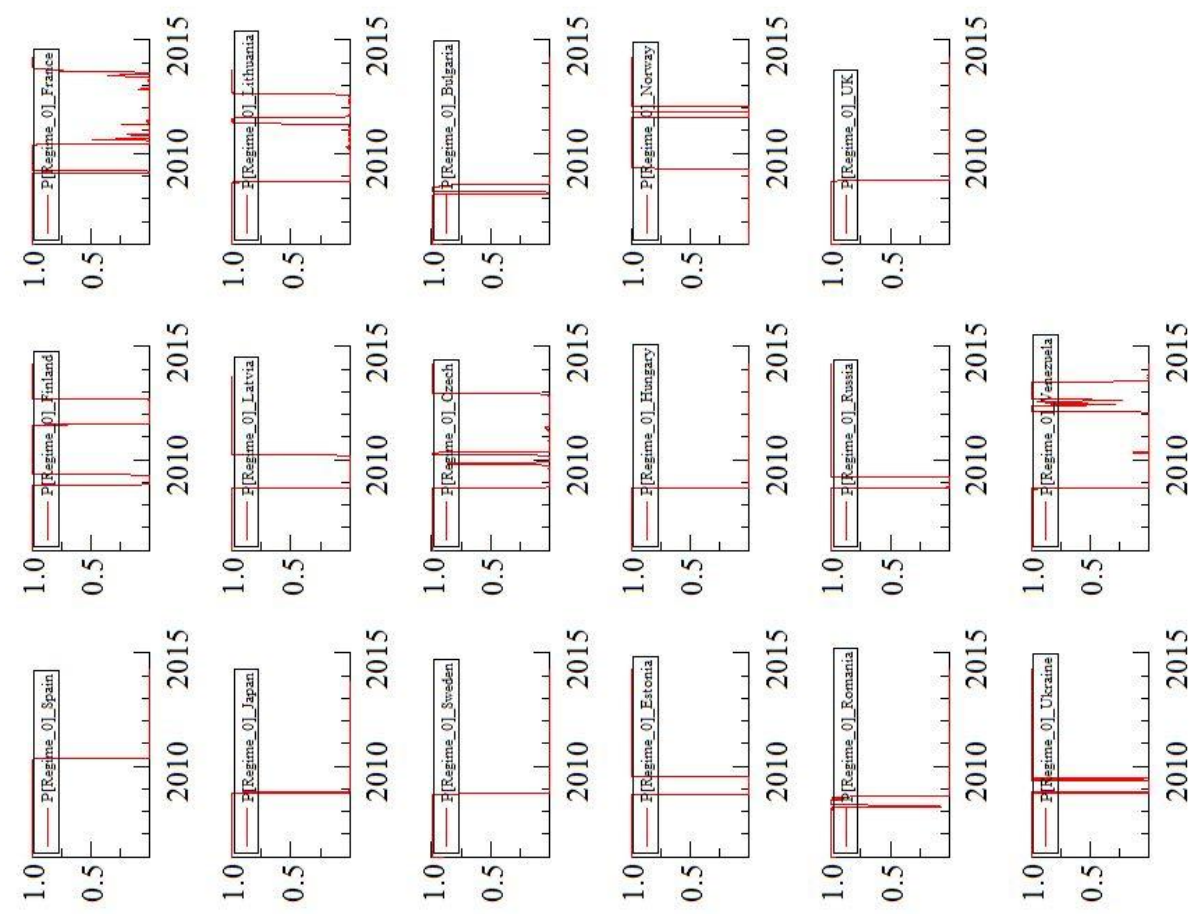

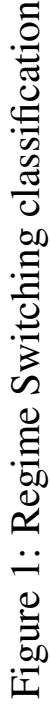
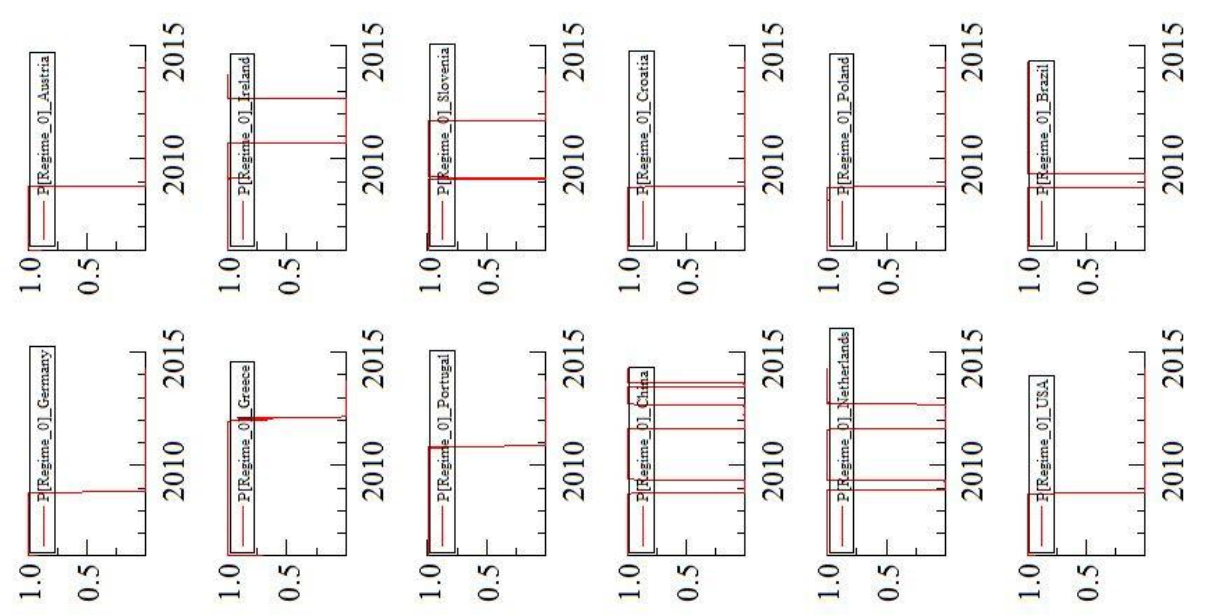
AR (1) as follows:

$$
x_{i, t}=\ln \left(S_{i, t}\right)-\ln \left(S_{i, t-1}\right)=a_{i, 0}+\alpha_{1} x_{i, t-1}+\varepsilon_{i, t} .
$$

with $S_{i, t}$ is the time series of a country $\mathrm{i}$ at time t. This AR(1) representation can be written as:

$$
(1-\alpha L) x_{i, t}=a_{i, 0}+\varepsilon_{i, t} .
$$

where $L$ is the lag operator, $i$ is a given country from the sample, $a_{0}$ is a constant $\in[0, \infty),|\phi|<1$ and $\varepsilon_{t}=e_{t} \sigma_{t}$ with $\varepsilon_{t} \rightsquigarrow N\left(0, \sigma_{t}^{2}\right)$ is a discrete time realvalued stochastic process, $e_{t}$ constitute a white noise and are independently and identically distributed such as $E\left(e_{t}\right)=E_{t}\left(e_{t-1}\right)=0 . \sigma_{t}^{2}$ is a positive parameter representing the conditional variance of $x_{t}$ such as $\sigma_{t}^{2}=\operatorname{Var}\left(x_{t} / \mathcal{F}_{t-1}\right)$ with $\mathcal{F}_{t}$ is the market information at a given moment t. Hence, the $\operatorname{AR}(1)$ allows us to quantify the speed market information's integration in the CDS spreads returns.

\subsection{EWMA model}

The use of the EWMA method in the literature to quatify contagion is justified by several reasons: (i) it allows us to analyze the underlying dynamics of correlations within each period while other methods only permit to calculate correlations for a number of sub-periods (Coudert and Gex, 2010). (ii) This method makes a common interest into past and present observations in such a way that it can detect small shift more easily and quickly, when other methods only take into account most recent data by forgetting the past ones (Ferreira and Lopez, 2005; Raza, Prasad and Li, 2015). (iii) Yet, since time-series data are characterized by the fact that recent observations have a greater impact on second moments than older ones, the EWMA model gives more weight to recent data relative to past ones using a weighting constant parameter. Thereby, researchers argue that the use of EWMA model is preferable to other complicated models in estimating dynamic conditional correlations (Ferreira and Lopez, 2005; Coudert and Gex, 2010; Kalbaska and Gatkowski, 2012; Raza et al., 2015).

The EWMA volatility is defined as a moving average of the quadratic returns of our time series $\left(x_{t}\right)$ weighted by a sequence of smoothing parameters:

$$
\sigma_{t}^{2}=\frac{1}{n} \sum_{k=1}^{n} \alpha_{k} x_{t-k}^{2} .
$$

The weights $\alpha_{k}$ decrease as we go back in time. Each quadratic return is weighted by a ad hoc structure defined by a lambda parameter in the following way: $\alpha_{k+1}=$ $\lambda \alpha_{k}=\lambda^{2} \alpha_{k-1}=\ldots=\lambda^{n+1} \alpha_{k-n}$

with $\lambda$ is the smoothing parameter also known as the decay factor such as $0<$ $\lambda<1$. 
According to Morgan (1996), the optimal smoothing parameter is given by finding the smallest root mean square error of the variance forecast ${ }^{12}$ over different values of $\lambda$. The use of the RMSE criterion on 480 financial time series show that $\lambda$ for the daily data set is equal 0.94 , and the $\lambda$ for the monthly data set is equal to 0.97. Coudert and Gex (2010) find that $\lambda=0.94$ in a sample composed by CDS of 226 European and American firms, while Kalbaska and Gatkowski (2012) find $\lambda=0.939$ in a sample composed by European sovereign CDS. Furthermore, other strand of the literature find that $\lambda$ in mostly equal to 0.5 which seems to be underestimated since the sample is very small. In this paper, $\lambda$ is assumed to be equal to 0.939 .

Variance can, also, be rewritten as a function of $\lambda$ as follows:

$$
\sigma_{t}^{2}=\frac{\sum_{k=1}^{n} \lambda^{k-1} x_{t-k}^{2}}{\sum_{k=1}^{n} \lambda^{k-1}} .
$$

When the dataset contains an infinite number of observations, which is close to our case with a large number of data, the EWMA variance is equivalent to an $\operatorname{IGARCH}(1,1)$ :

$$
\sigma_{t}^{2}=(1-\lambda) x_{t-1}^{2}+\lambda \sigma_{t-1}^{2} .
$$

By analogy to the variance expression, the EWMA covariance between two times series ( $i$ and $j$ ) can also be defined as an autoregressive form as follows:

$$
\sigma_{i j, t}=\operatorname{Cov}\left(x_{i, t}, x_{j, t}\right)=(1-\lambda) x_{i, t-1} x_{j, t-1}+\lambda \operatorname{Cov}\left(x_{i, t-1}, x_{j, t-1}\right) .
$$

Given that the correlation is the covariance between the two returns $\left(x_{i, t}, x_{j, t}\right)$ divided by their variance, we can conclude the correlation equation:

$$
\rho_{i j, t}=\frac{\operatorname{Cov}\left(x_{i}, x_{j}\right)_{t}}{\sigma_{i, t} \sigma_{j, t}}=(1-\lambda) \frac{x_{i, t-1} x_{j, t-1}}{\sigma_{i, t-1} \sigma_{j, t-1}}+\lambda \rho_{i j, t-1} .
$$

with $\mathrm{i}$ is a country where the crisis initially triggers and $\mathrm{j}$ is a given country from the sample. $x_{j, t}$ and $x_{j, t}$ are financial time series of respectively countries $\mathrm{i}$ and $\mathrm{j}$.

\subsection{A bivariate FIEGARCH-DCC model}

The second approach used for investigating the contagion phenomena is based on a multivariate Fractionally Integrated Exponential GARCH (FIEGARCH) dynamic conditional correlation (DCC) framework introduced by Bollerslev and Mikkelsen (1996). This method has already been used to identify volatility spillover

\footnotetext{
${ }^{12} R M S E_{v}=\sqrt{\frac{1}{n} \sum_{i=1}^{n}\left(x_{i+1}^{2}-\sigma_{i+1}^{2}(\lambda)\right)^{2}}$.
} 
effects between oil prices and different stock markets indices by Youssef and Belkacem (2015).

Baillie, Bollerslev and Mikkelsen (1996) argue that financial assets' conditional volatility may be more persistent than what is captured by ordinary ARCH and GARCH models and suggested the use of a new class of Fractionally Integrated Generalized AutoRegressive Conditionally Heteroskedastic model instead of a standard GARCH model. Bollerslev and Mikkelsen (1996) extend this new class of Fractionally Integrated process and suggest that financial market volatility is best estimated by a mean-reverting fractionally integrated model. The relevance and the reliability of the FIEGARCH specifications for characterizing financial assets' volatility are illustrated by empirical findings based on the U.S stock market. The same conclusion could be relevant in the case of correlations.

Moreover, Conrad et al. (2011) recommend the use of this class of models since it increases flexibility of the conditional variance and includes several GARCH specifications in the volatility process. In fact, The FIEGARCH model allows (i) an asymmetric response of volatility to positive and negative news, (ii) a long-range volatility dependence (Surgailis and Viano, 2002; Christensen et al., 2010; Günay, Shi et al., 2016) and (iii) it allows the data to determine the power of returns for which the predictable structure in the volatility pattern is the strongest (Ruiz and Veiga, 2008; Conrad et al., 2011). Fantazzini (2011) discuss empirical examples and show that the FIEGARCH outperforms other fractional models for volatility. It is the one that fits the best in terms of convergence, computational time and diagnostic tests ${ }^{13}$.

The dynamic conditional correlation estimation using the FIEGARCH model needs to go through two-steps process:

\section{The first step: a univariate process}

A univariate FIEGARCH $(1, \mathrm{~d}, 1)$ model is estimated for each of the time series in order to obtain the estimations of $\sigma_{i i, t}$ following the same process used by Youssef and Belkacem (2015), Goudarzi and Ramanarayanan (2010), Ruiz and Veiga (2008) and Bollerslev and Mikkelsen (1996).

According to Bollerslev and Mikkelsen (1996), a FIEGARCH (p,d,q) model is written as follows:

$$
\ln \left(\sigma_{t}^{2}\right)=c_{0}+\phi(L)^{-1}(1-L)^{-d}[1+\psi(L)] g\left(e_{t-1}\right),
$$

\footnotetext{
${ }^{13}$ The Ljung-Box tests (Q-statistics), the Residual-Based Diagnostic, the Nyblom test for stability and the Adjusted Pearson Godness-of-fit test. See the Review-Empirical Appendix of Fantazzini (2011) for detailed description of theses diagnostic tests.
} 
with $(1-L)^{-d}$ is the financial fractional differencing operator ${ }^{14}, \phi(L)$ and $\psi(L)$ are lag polynomials.

And $g\left(e_{t}\right)$ is a quantization function of information flows such as $g\left(e_{t}\right)=\theta e_{t}+\gamma[\mid$ $\left.e_{t} \mid-E\left(\left|e_{t}\right|\right)\right]$ where $\gamma$ is the leverage coefficient. When $\gamma>0$, it means that the impact of bad news (negative shocks) on volatility is more important than the impact of good news (negative shocks with the same absolute magnitude), leading to an increase of the conditional variance in a more proportionally way and vise versa:

$$
\left\{\begin{array}{l}
g\left(e_{t}\right)=(\theta+\gamma) e_{t}-\gamma E\left[\left|e_{t}\right|\right], \text { if } e_{t} \geq 0 \\
g\left(e_{t}\right)=(\theta-\gamma) e_{t}-\gamma E\left[\left|e_{t}\right|\right], \text { otherwise }
\end{array}\right.
$$

In contrast to FIGARCH model, the $\operatorname{FIEGARCH}(p, d, q)$ is automatically welldefined and doesn't need any nonnegativity restrictions.

\section{The second step: a multivariate process}

In the second step, we draw on the work proposed in Tse and Tsui $(2002)^{15},{ }^{16}$ and we introduce the multivariate specification to the FIEGARCH model in order to estimate the conditional correlation. To do so, we use the standardized residuals defined in the first step of our methodology by their standard deviation.

The Dynamic conditional correlation model is defined as a time varying variancecovariance matrix:

$$
\Omega_{t}=D_{t} H_{t} D_{t}
$$

with $D_{t}$ is a diagonal matrix $N \times N$ such as $D_{t}=\operatorname{diag}\left(\sigma_{11, t} \ldots \sigma_{N N, t}\right), \sigma_{N N, t}$ is the conditional standard deviation obtained from the univariate model AR(1)FIEGARCH $(1, \mathrm{~d}, 1) . H_{t}$ is the correlation matrix of the standardized residuals $\varepsilon_{t}$ such as $H_{t}=\left\{\rho_{i j, t}\right\}$. $H_{t}$ is obtained from the recursion of

$$
H_{t}=\left(1-\theta_{1}-\theta_{2}\right) H+\theta_{1} H_{t-1}+\theta_{2} \Xi_{t-1}
$$

where the parameters $\theta_{1}$ and $\theta_{2}$ are supposed to satisfy the non-negativity constraint and the inequality $\theta_{1}+\theta_{2}<=1$. H is a time invariant matrix $\left(\rho_{i j}>0\right)$ with

\footnotetext{
${ }^{14}$ The differencing operator is defined by its Maclaurin series expansion. In the branch of mathematical analysis, a Taylor serie of a function $\mathrm{f}$ (at a single point a) is a representation of power series calculated from the successive values of $\mathrm{f}$ and its derivatives at the point $\mathrm{a}$. If $\mathrm{a}=0$ then the serie is so-called Maclaurin serie expansion. $(1-L)^{d}=(1-d) \sum_{h=1}^{\infty} \Gamma(h-d) \Gamma(1-d)^{-1} \Gamma(h+1)^{-1} L^{h}=$ $1-\delta_{d}(L)$ with $\Gamma$ is the gamma function (it is a a special function that extends the factorial function to the whole set of comlex numbers, hence the name of function $f$ complex variables.).

${ }^{15}$ See also Engle (2002) and Engle and Kelly (2012) for further DCC estimation methods. They propose another class of multivariate model allowing some new specifications on the correlation matrix calculation.

${ }^{16}$ Conrad et al. (2011) present a different formulation of the multivariate DCC model and applied it to study the contagion effect on the national stock market.
} 
a unit diagonal element $\left(\rho_{i i}=1\right)$ and $\Xi_{t-1}$ is the correlation matrix of lagged estimations of $\varepsilon_{t}$. Tse and Tsui (2002) require $\Xi_{t-1}$ to depend on the lagged residuals so, analogously to the $x_{t-1}^{2}$ in the $\operatorname{GARCH}(1,1)$ representation, they let $\Xi_{t-1}$ to be specified by the following formula:

$$
\Xi_{i j, t-1}=\frac{\sum_{s=1}^{S} e_{i, t-s} e_{j, t-s}}{\sqrt{\left(\sum_{s=1}^{S} e_{i, t-s}^{2}\right)\left(\sum_{s=1}^{S} e_{j, t-s}^{2}\right)}}, 1 \leq i<j \leq M .
$$

Furthermore, $S \leq M$ is a necessary condition to make $\psi_{t-1}$ positive definite and so for $\Gamma_{t-1}$. So, in our bivariate case, the conditional correlation coefficient is defined as:

$$
\rho_{12, t}=\left(1-\theta_{1}-\theta_{2}\right) \rho_{12}+\theta_{1} \rho_{12, t-1}+\theta_{2} \frac{\sum_{s=1}^{S} e_{1, t-s} e_{2, t-s}}{\sqrt{\left(\sum_{s=1}^{S} e_{1, t-s}^{2}\right)\left(\sum_{s=1}^{S} e_{2, t-s}^{2}\right)}} .
$$

\subsection{DCC behavior over time}

One of the most common methods of detecting contagion, is to verify whether there is significant increase in correlations between different countries from one period to another. To do so, Coudert and Gex (2010), Kalbaska and Gatkowski (2012), Dimitriou et al. (2013) and Kenourgios and Dimitriou (2015) estimate regressions putting in relationship conditional correlations $\left(\rho_{i j, t}\right)$, their lagged values $\left(\rho_{i j, t-1}\right)$ and dummy variables representing different crisis periods $\left(D_{k}\right)$. We follow this approach and we consider the following equation:

$$
\rho_{i j, t}=\alpha_{i j, 0}+\alpha_{i j, 1} \rho_{i j, t-1}+\beta_{i j, k} D_{k}+\eta_{i j, t} .
$$

where $\alpha_{0}$ is a constant $\in[0, \infty), \eta_{t}$ represents the innovations, $\rho_{i j, t}$ is the pairwise conditional correlation at time $t$ with $i$ is the crisis generator (USA, Greece or Ireland) and $\mathrm{j}$ refers to another country from the sample. $\mathrm{k}$ corresponds to the crisis index, it is equal to 1 when it's about the first financial crisis and equal to 2 when it comes to the European Debt Crisis.

We consider these OLS regressions on every countries' pairwise since estimations in time series are more reliable than panel analysis (Chiang et al., 2007).

\section{Empirical results}

\subsection{Summary statistics and data analysis}

Table 2 shows descriptive statistics for CDS spreads (in level and log returns) during studied period running from January $2^{\text {nd }}, 2006$ until April $3^{\text {rd }}, 2014$ for a total 
of 2154 daily observations. Panels A, B, C and D correspond to summary statistics of respectively PIIGS, developed countries, newly industrialized countries and emerging countries. The average CDS spreads ranges from 28,124 bp (Finland) to 876.060 (Venezuela) regardless of Greece. In a general manner, CDS markets are highly volatile since the lowest standard deviation is recorded in Norway (18.123\%). Greece is obviously the most risky market with the greater volatility (which is not very surprising given the nature of indebtedness in this country ${ }^{17}$ ). Moreover, The minimums and maximums are not at the same magnitude and vary a lot from one country to another which highlights evidently the heterogeneity of the 35 countries composing our sample.

The ADF test confirms the existence of a unit root in all the CDS spreads series. We cannot reject the null hypothesis of the presence of unit root. CDS spreads are integrated of order 1. Thus, logarithmic returns of CDS spreads are used rather than CDS spreads in level in order to have stationary time series.

$$
x_{i, t}=\log \left(S_{i, t}\right)-\log \left(S_{i, t-1}\right) .
$$

where $S_{i, t}$ is the CDS spread of country $i$ at the instant $t$.

First, based on the results of normality tests (Table 2), most of CDS log returns present positive skewness coefficients, meaning that the log returns distribution is skewed to the right (long right tail). In fact, the probability of observing extreme positive returns is higher than that of a normal distribution which highlights the asymmetry of investors' behaviors towards market information. Second, Kurtosis coefficients are always significant and greater than 3 , which indicates the presence of a leptokurtic behavior of our data which implies that the pattern of our data distribution in more peaked than that of a normal distribution. This means that extreme events -such as large prices changes- are more frequent than in a normal distribution and last generally much longer contrary to small changes of our data. Finally, The Jarque-Bera test (Table reftab2)) rejects the null hypothesis of normal distribution at $1 \%$ significant level and confirm, thus, the results of skewness and kurtosis tests. To overcome the non-normality of all our time series, log returns of CDS spreads are supposed to follow a Student's t-distribution.

Furthermore, the ARCH-LM tests (Table 3 ) reveal the times series' heteroscedasticity and confirm the existence of an ARCH-type effect in all CDS spreads log returns (Except for Greece, Lithuania and Slovenia). Moreover, several tests are applied to check for the volatility long-memory path. Absolute returns and squared returns are used as proxies for unconditional volatilities. Results for both Gaussian semi-parametric (Robinson and Henry, 1999) and log periodogram (Geweke

\footnotetext{
${ }^{17}$ According to Eurostat data, Greece recorded the highest public indebtedness increase among the European Union countries during the sample period. The Greek public debt rose by $65 \%$ spreading from $106.1 \%$ of GDP in 2006 to $175.1 \%$ of GDP early 2014 .
} 
and Porter-Hudak, 1983) estimates show that long memory path is observed for all studied CDS spreads. ${ }^{18}$

This preliminary analysis clearly suggests the run of a GARCH family model taking into consideration several properties: Volatility clustering, long-memory process, asymmetry and leverage effects. Cross markets' correlations are estimated using a FIEGARCH-DCC approach.

Focusing on the CDS spreads paths of PIIGS (Fig. 2), we see that levels of spreads were low until the end of 2007 which indicates that the market doesn't expect any credit event and the default risk on the underlying debt is very weak: the CDS market is hitherto underdeveloped. The first change in the path of the credit derivative market took

\footnotetext{
${ }^{18}$ According to Robinson and Henry (1999) and Geweke and Porter-Hudak (1983), the use of an autoregressive fractionally integrated moving average for volatility model is suitable when time series present long memory behavior.
} 


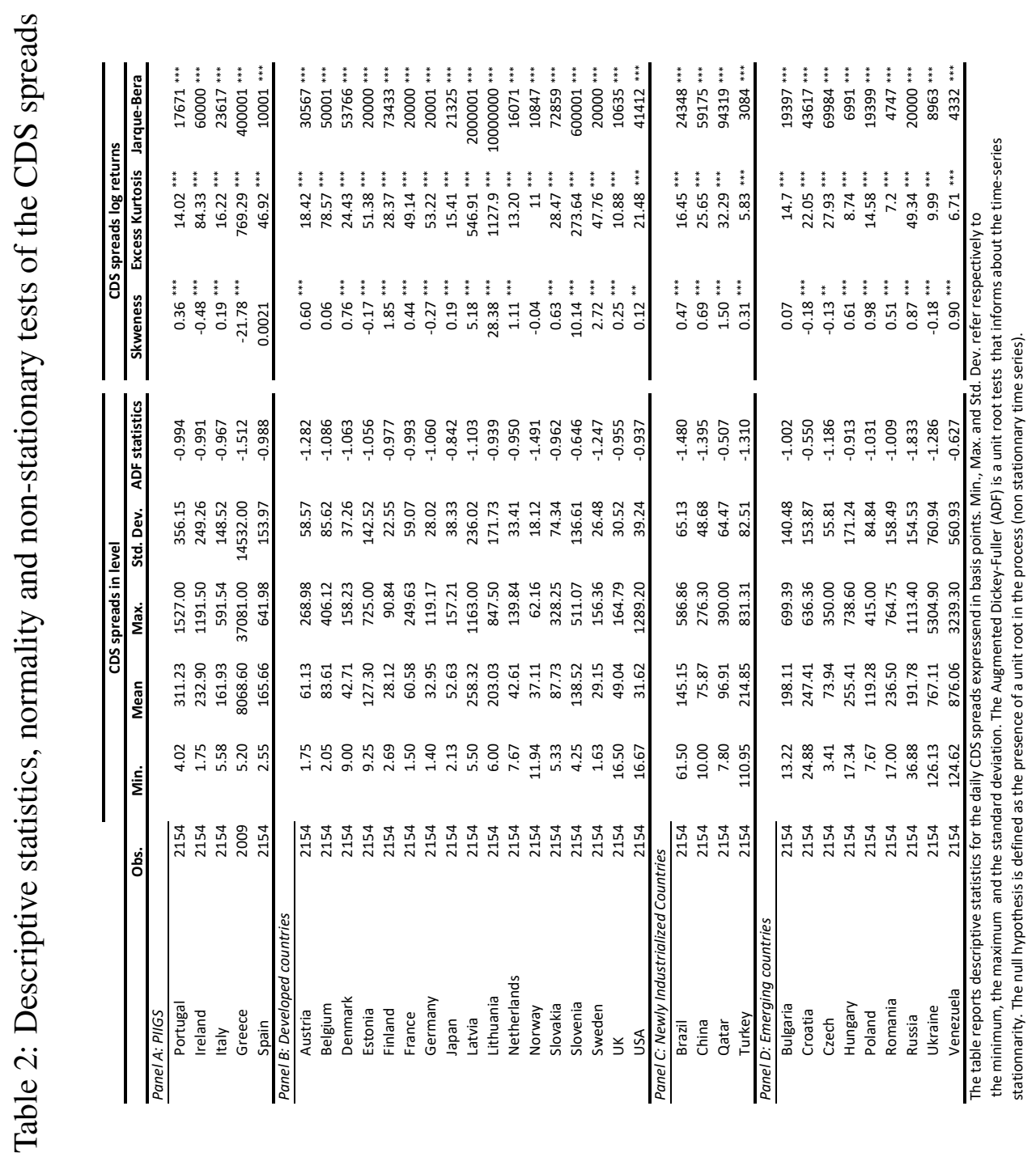




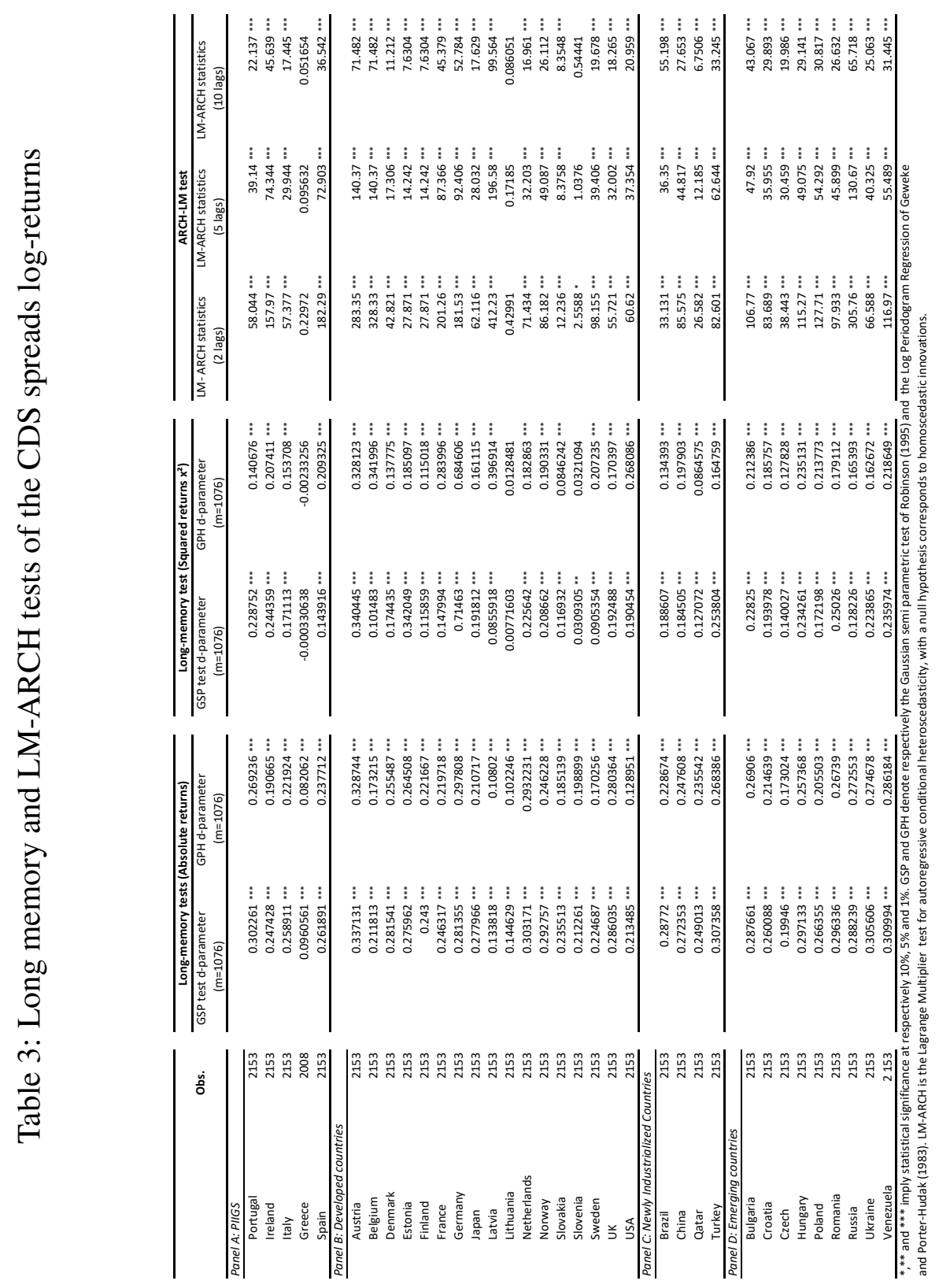


place around August 2007 and the first increases in CDS spreads were recorded around December 2007. These spreads have grown drastically after the triggering of the European debt crisis between October, 2009 and April, 2010 with the increase in investor uncertainty about the ability of Greece to repay its debts. Greek CDS spreads continue to increase, even after the adoption of the EU-IMF bailout measures in May 2010, recording peaks at very high levels since investors continue to reevaluate upwards the credit risk of Greece. CDS spreads of Portugal, Ireland, Italy and Spain follow the same movements of Greek CDS spreads but in a smaller magnitude. Except for some small declines in response to rescue operations, spreads were rising steadily until mid 2012. From that date, a downward trend was observed in these countries' CDS markets.

For developed countries, no uniform behavior is seen in CDS markets. In almost all countries (except for Slovenia, Estonia, Latvia and USA.), the pattern of CDS spreads seems to have an uptrend with two major peaks in 2009 and 2012. We can clearly see a return to previous values after 2012. For emerging and Newly Industrialized countries CDS spreads levels were already high even before the first crisis period. The CDS prices in these countries considerably increased after the credit crunch and the triggering of the European debt crisis, suggesting that investors worry about the impact of Greek solvency problems. Hence, it can be seen that crisis periods sparked a contagion surge in the CDS market behavior of almost all studied countries. Nevertheless, behavioral differences are recorded between PIIGS, developed countries, emerging countries and newly industrialized countries. This suggests that the level of exposure to crises is different from one country to another. The previous findings suggest an international transmission of crisis since (i) the exposure of European market to American banking system crisis is relatively high and (ii) the American CDS market react to Greek problems.

\subsection{EWMA conditional correlations analysis}

The EWMA dynamic correlations is estimated between the sample countries and the crises originators - namely USA for the first crisis and Greece and/or Ireland for the second crisis. Then, they are tested over several sub-periods in order to detect any significant variation between the crises' periods and the reference period.

Fig. 3 shows the evolution of the average EWMA correlations of the 35 studied countries, regardless the crises' sources. This evolution pattern confirms once again that our studied period can be divided into 4 sub-periods. The lowest average correlation's values are recorded during the pre-crisis period. During crises' phases, world wide correlations tend to increase depicting the occurrence of contagion phenomena on the sovereign CDS market. Interestingly, we see that, initially, countries' behavior towards Greece and Ireland is close. After 2010, countries CDS markets detached themselves from Greece, but continued to stay correlated 
to Ireland, probably because of of its banking-based economy. Markets' behavior towards the USA is different,obviously because of the difference in crisis nature (although both are related of course).

The curves of Fig. 4, Fig. 5 and Fig. 6 depict the evolution of correlations between crisis originators and the other countries on a country-level basis. Before the credit crunch in July, 2007 correlations among USA and all countries around the word were at their lowest levels, while after the release of the crisis, correlations recorded significant increases. The levels of correlations keep increasing after the triggering of the European debt crisis by the end of 2009. These same curves show a stabilization of the correlations by the end of 2009 mainly for low economic growth countries (PIIGS). Even if it is very brief and poorly significant, this stabilization can be justified by the fact that the 

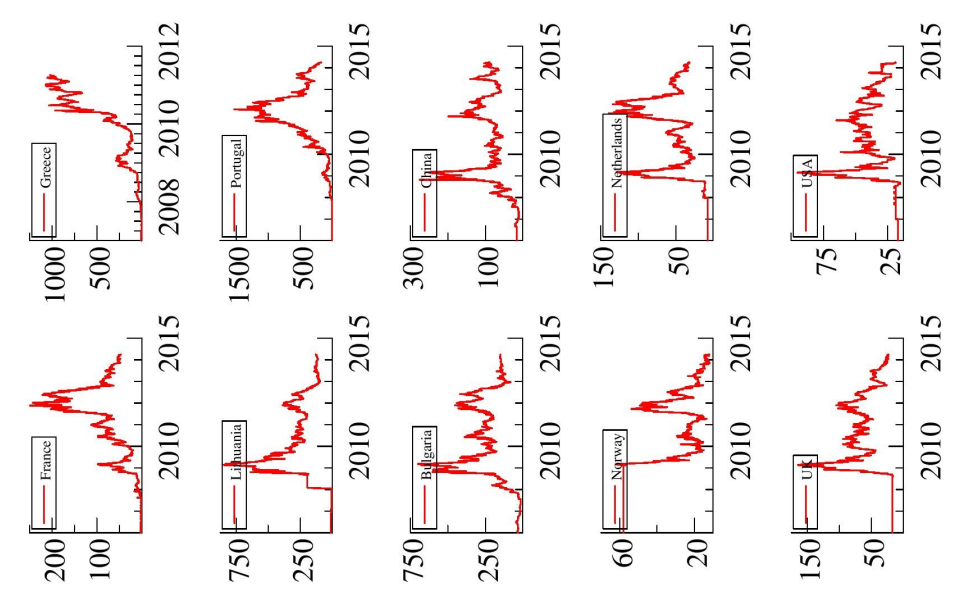

융
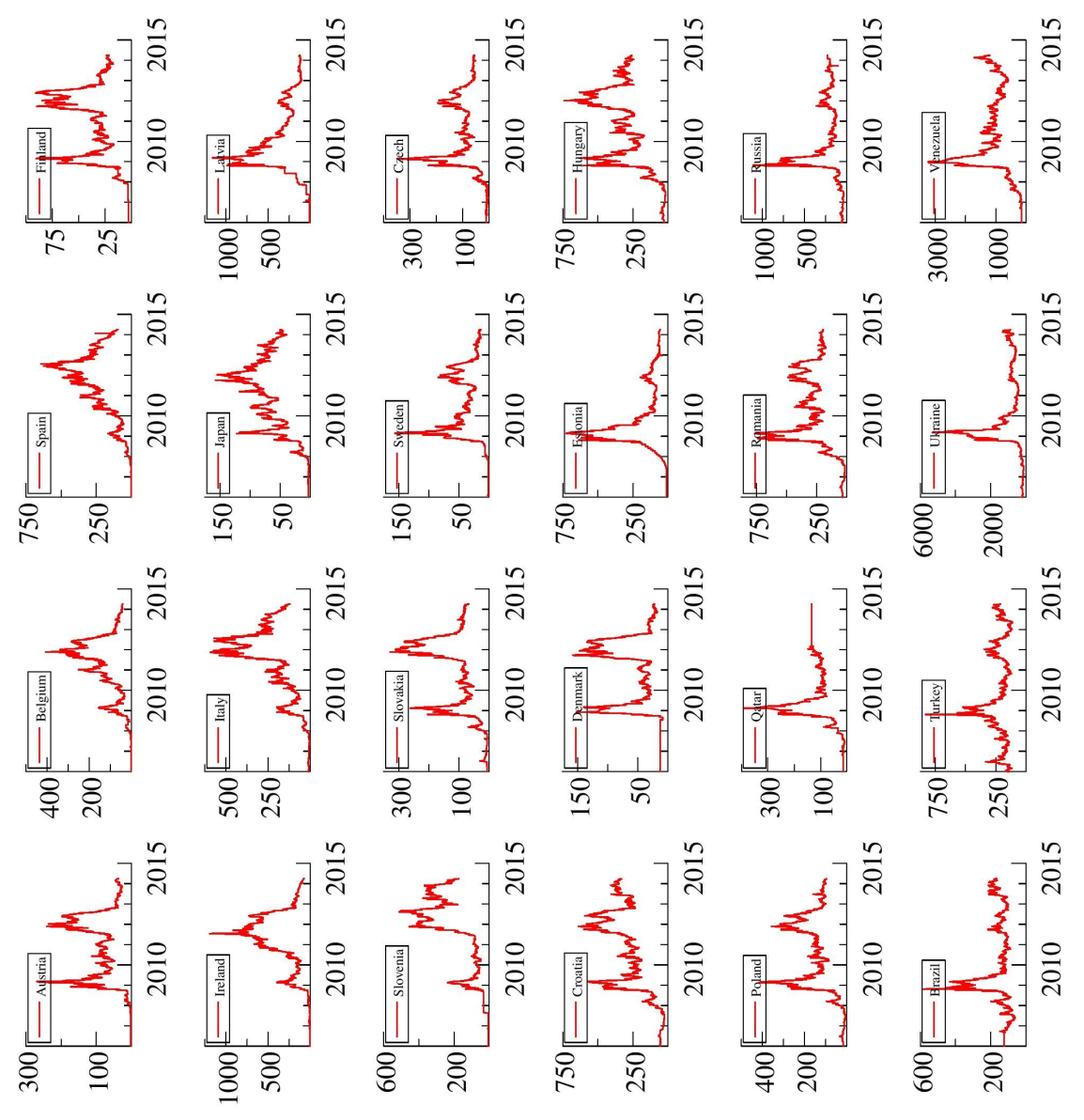

告 


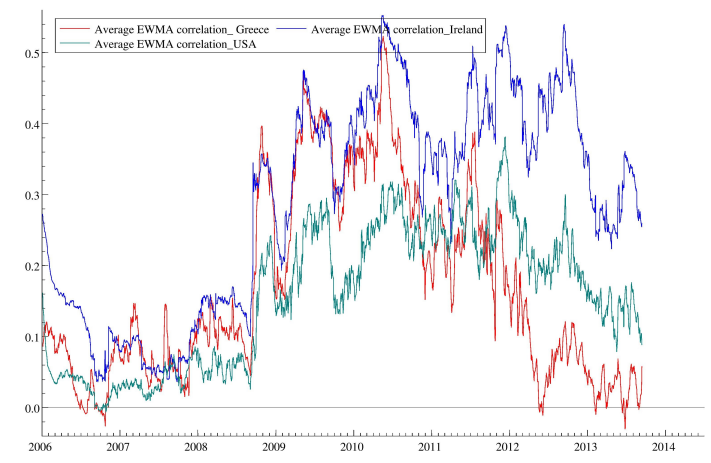

The average of all countries correlations with the crisis source country.

European central bank set up rescue package for most countries affected by the financial distress allowing them to come through the credit crunch. However, this tranquil phase is brief because the transfer of private debts to the sovereign sector, worsen the financial situation and make the correlations between Greece, Ireland and countries from the sample record some drastic increases during 2010. In spite of the ceaseless bailout operations to rescue the financial situation, correlations pursue the increase reflecting a contagion effects affecting more and more European and world wide countries.

Referring to results of these OLS regressions (Results are not reported here but can be given upon request), the approach seems to detect more contagion spillover among worldwide countries during the second crisis period (23 and 27 significant correlations' increases respectively when Greece and Ireland are crisis generators) compared to the first crisis period (only 14 significant increases). This implies, at first sight, that the European debt crisis's intensity and severity are more important than in the GFC. In fact, many countries around the world, that present a decoupling behavior during the credit crisis, become subject to contagion effects during the sovereign debt crisis (Finland, Latvia, Hungary, China...). Aggregate results show that developed and emerging countries are prone to several contagion waves through the studied period. More detailed results are exposed in the next subsection.

\subsection{The bivariate AR(1)-FIEGARCH-DCC model analysis}

We present in this section the estimation results the univariate $\operatorname{AR}(1)-\operatorname{FIEGARCH}(1, \mathrm{~d}, 1)$ (Table 4) and the multivariate FIEGARCH-DCC model (Table 5) among USA, Greece, Ireland and other countries from the sample. 
As supposed in the previous section, results of the univariate process show that most of time series follow an autoregressive term (AR(1)) statistically positive and significant, meaning that pertinent information is automatically and instantly integrated in the CDS market prices (except for Slovakia, Sweden, China, Croatia and Czech). Table 4 shows, as well, that the CDS markets present, mainly, a fractional differencing motion represented by the significant parameter $d^{19}$. Yet, the statistical significance of the model parameters confirms the relevance of the FIEGARCH $(1, \mathrm{~d}, 1)$ use.

The multivariate model findings (Table 5) show that the t-student degrees of freedom represented by the parameter $(d f)$ is strongly significant at $1 \%$ level whatever the crisis generator is, confirming once again the Jarque-Bera results and the appropriateness of the student distributed innovations assumption instead of a Gaussian distribution. Furthermore, average conditional correlation $R h_{12}$ is mostly significant between the full sample countries. In fact, USA - as the subprime crisis generator - is the most correlated with developed countries and western Europe while it is the least correlated with emerging countries and Eastern Europe. Besides, it is higher among Greece (or Ireland ${ }^{20}$ ) and PIIGS and Greece (or Ireland) and Eastern Europe and lower among Greece (or Ireland) and NIC and emerging countries.

As mentioned before, statistical significance of these dummy variables implies structural changes in conditional correlations pattern over time owing to financial shocks. Concretely, when $\beta_{k}$ (of the Equation (14)) is significant and positive, it means that correlation level has increased during the period $\mathrm{k}$ compared to the tranquil period, justifying, thus, the presence of a contagion effect on the CDS market. Conversely, a negative and/or insignificant dummy variable confirms a decoupling assumption between sovereign CDS markets. Results are reported in Table 6. During the first crisis period - namely the global financial crisis - $\beta_{1}$ is Significantly positive in 12 time series and Significantly negative in 4 among the 34 studied pairwises. This statistical significance is mostly recorded among developed countries. Contagion phenomenon exists in Italian, Spanish, Australian, danish, Norwegian, Slovakian, Slovenian, British, Qatar, Turkish, Russian and Ukrainian markets while the other markets of the sample are decoupled from the Global financial crisis and no crisis transmission between USA and these countries is observed. According to consolidated results, increasing dependence is observed between USA and developed countries, emerging countries and newly industrialized countries, from the one hand, and between USA and eastern Eu-

\footnotetext{
${ }^{19}$ According to Dimitriou et al. (2013), when the parameter $d$ is greater than 0.5 and highly significant, it means that there is a high degree of persistence behavior in financial markets. this indicates that the shock persistence on the conditional volatility of financial assets' returns is following an hyperbolic rate of decay.

${ }^{20}$ Greece and Ireland as the European Debt crisis generators present mainly the same results
} 
rope and Asia from the other hand. The EWMA model presents, more or less, the same results except that AR(1)-FIEGARCH-DCC model capture more significant relationships during the first financial crisis.

During the second crisis period the European Debt crisis, there is no big difference between EWMA and AR(1)-FIEGARCH-DCC results. Based on the hypothesis that the crisis has initially started in Greece, both emerging countries and PIIGS are strongly affected by contagion effects. This seems to be quiet obvious since (i) PIIGS and Greece have always had steady economic and geographical dependences and (ii) emerging countries are facing a complicated period of economic slowdown making them permanently more vulnerable than other countries. Yet, sovereign CDS markets in Eastern Europe and in America regions have been the most affected by this financial turmoil. 23 countries among the 34 studied present significant dummy coefficients $\left(\beta_{2}\right)$, implying their recoupling with the crisis. 


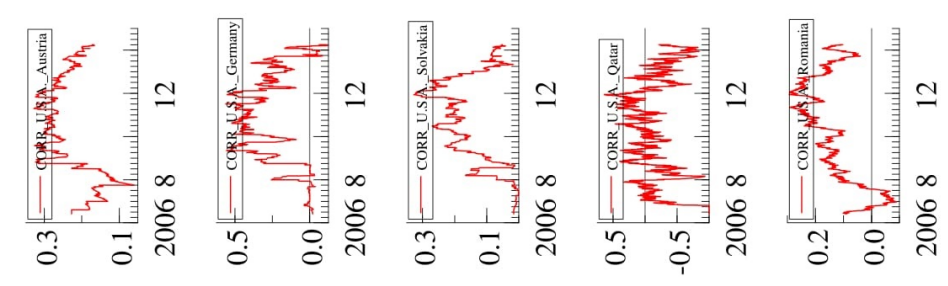

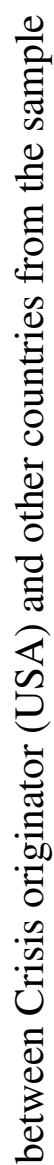
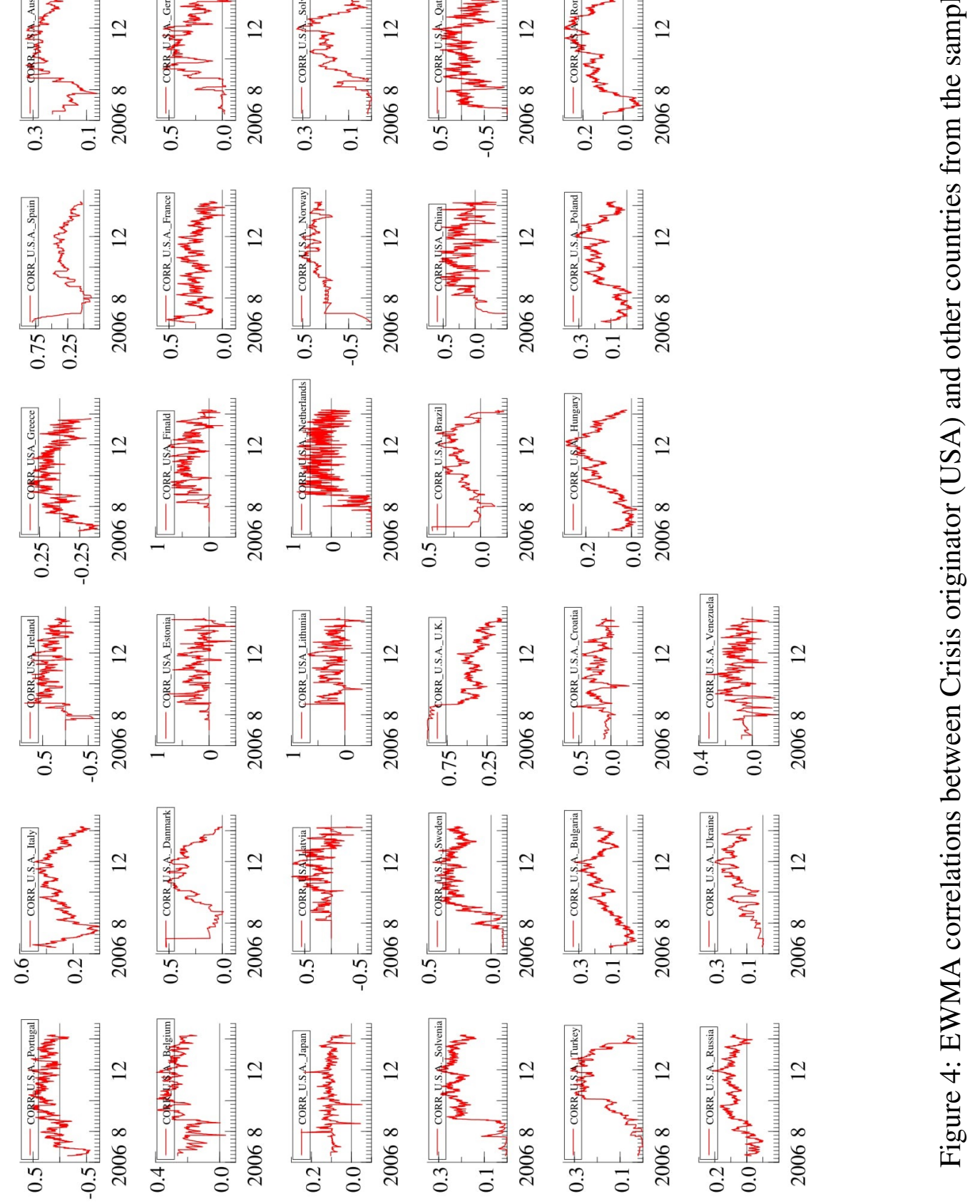


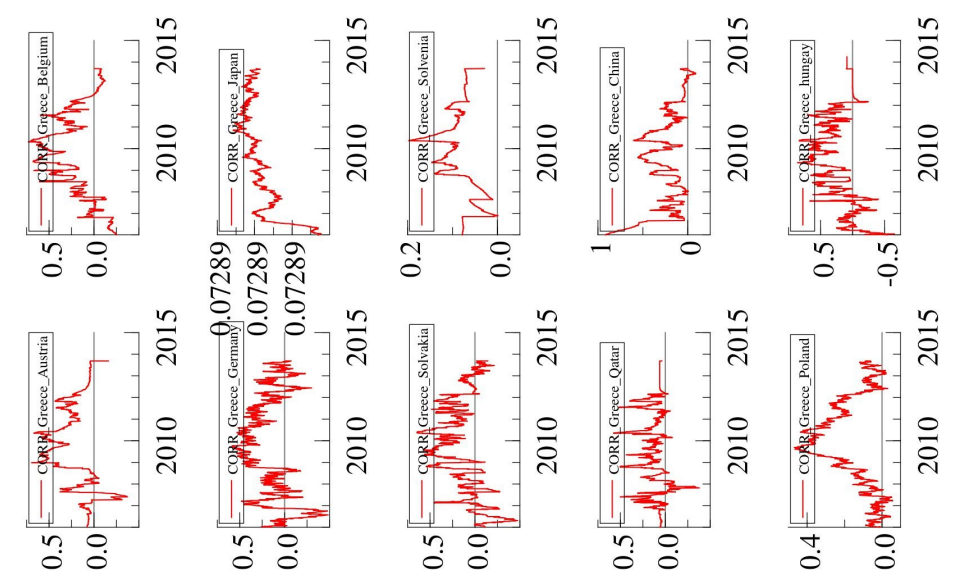

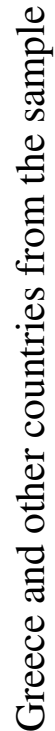

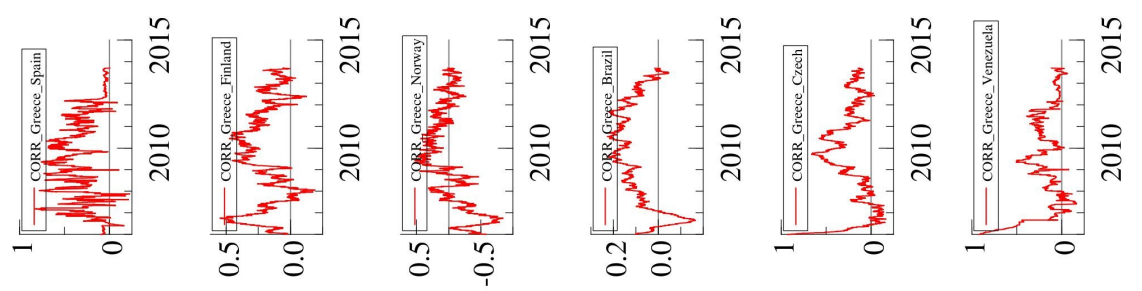

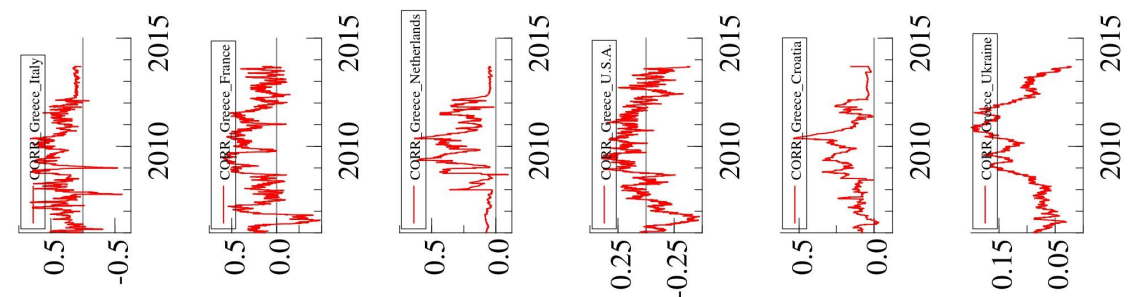

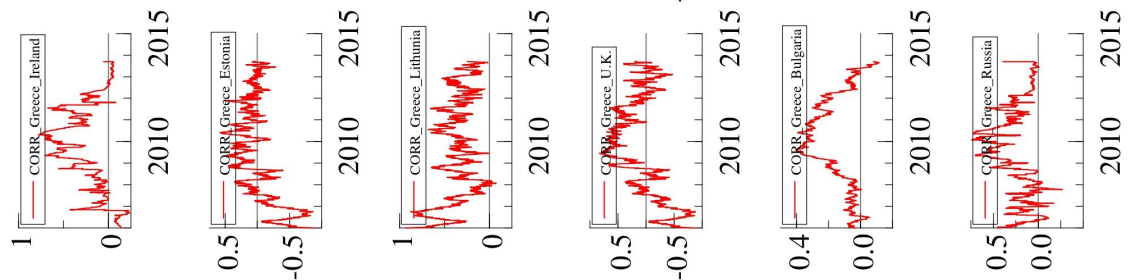

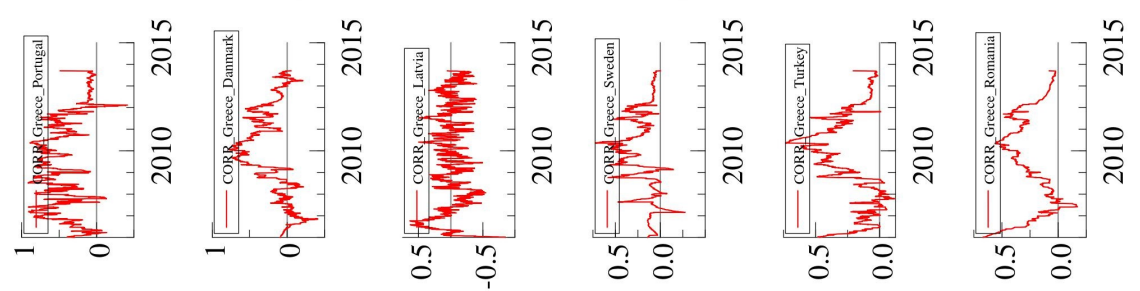

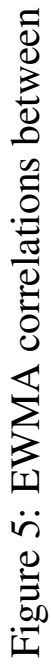




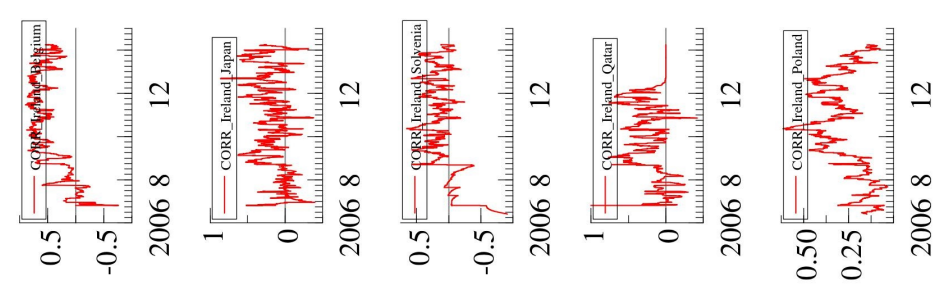

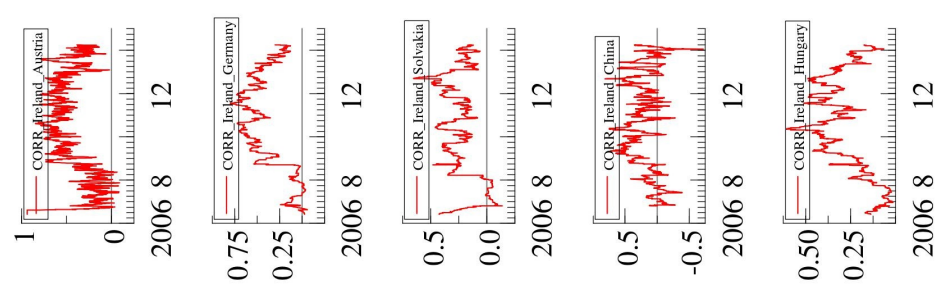

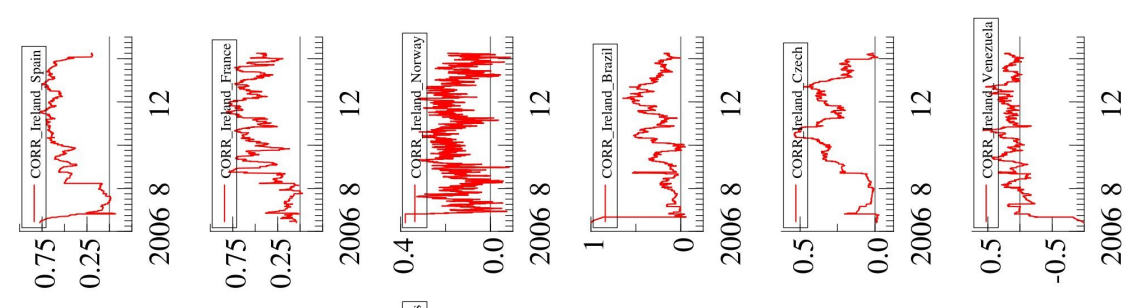

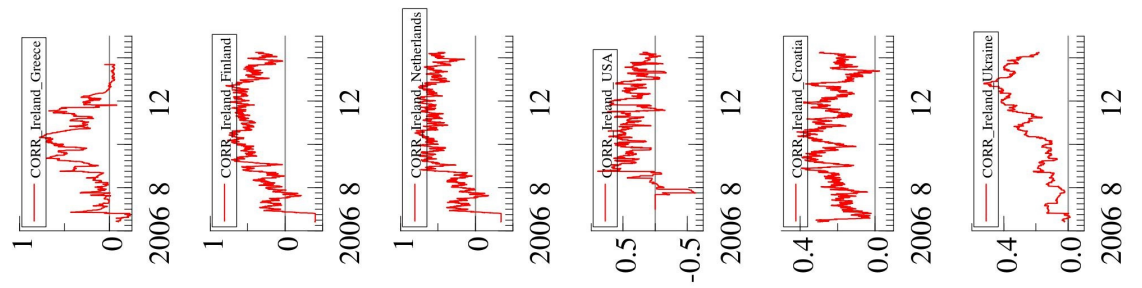
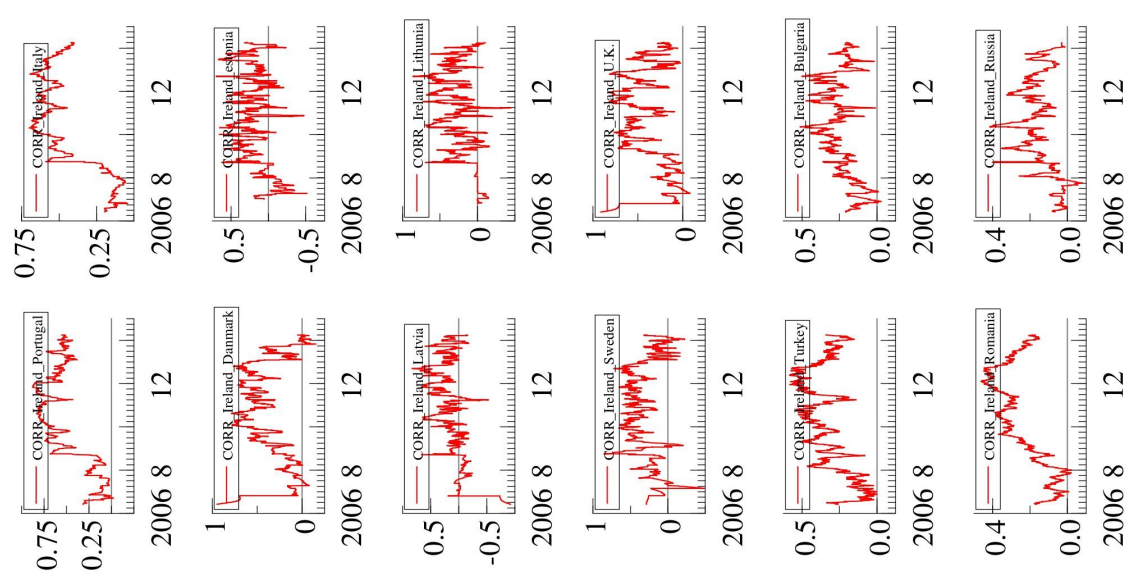
Supposing that the European Debt crisis has emerged from Ireland, all regional aggregate CDS markets around the world show evidence of contagion. Additionally, by focusing on the regional classification of CDS markets, we notice that Eastern Europe, Western Europe and Asia exhibit contagion effects. The crisis - initially touching Ireland - has spread - as expected - to PIIGS, to mostly all emerging countries and to newly industrialized economies. It has even reached several developed countries namely Austria, Belgium, France and Germany (The $2^{\text {nd }}$ crisis' dummy variables are significantly positive in 12 of the 17 developed studied countries).

\section{Discussion}

The regression of dynamic conditional correlations on crisis dummy variables approach shows a general contagion effect for most of the studied countries during both crises. Whether according to EWMA or to AR(1)-FIEGARCH-DCC results, strong evidences confirm the occurrence of contagion waves in both developed and emerging markets after the outbreak of the subprime crisis. Countries around the world (Western Europe, Asia...) are recoupling with USA since September, 2007.

These findings are consistent and can be economically explained. First, before and during the beginning of the subprime crisis, international investors didn't properly evaluate the banks' solvency risk given that the USA is considered as the least risky reference in the credit market. An underestimation of this crisis signal coupled with an unsustainable and drastic increase in investors' risk appetite towards the household mortgage debts and weak significant decisions were taken to stop the threats, have led the initially single-country crisis to worsen, to spread all over the world and to turn into a global financial depression similar to the great recession of 1929 (Rampell, 2009; Rampell, 2010; Evans-Pritchard, 2010). Developed countries have entered into a recession phase following the USA stock market crash by the end of 2008, namely most of European countries (France, Germany...) and even Asian countries (Japan...).

Second, according to the Global Financial Centers Index ${ }^{21}$, Wall street is the world's leading financial center. This advantage may explain the fact that all countries over the world invest in the USA stock market making then, naturally, vulnerable to any changes. In fact, as the global financial crisis intensifies - particularly

\footnotetext{
${ }^{21}$ The GFCI is a financial report published twice a year. The aim of this index is to examine countries' financial competitiveness. It rates and ranks more than 87 major financial centers in terms of their reactions to episodes of economic instability. Over several last years, New York and London remain the main occupiers of the first place as the worlds most economically powerful platform.
} 
Table 4: The univariate $\operatorname{AR}(1)-F I E G A R C H(1, d, 1)$ estimation results

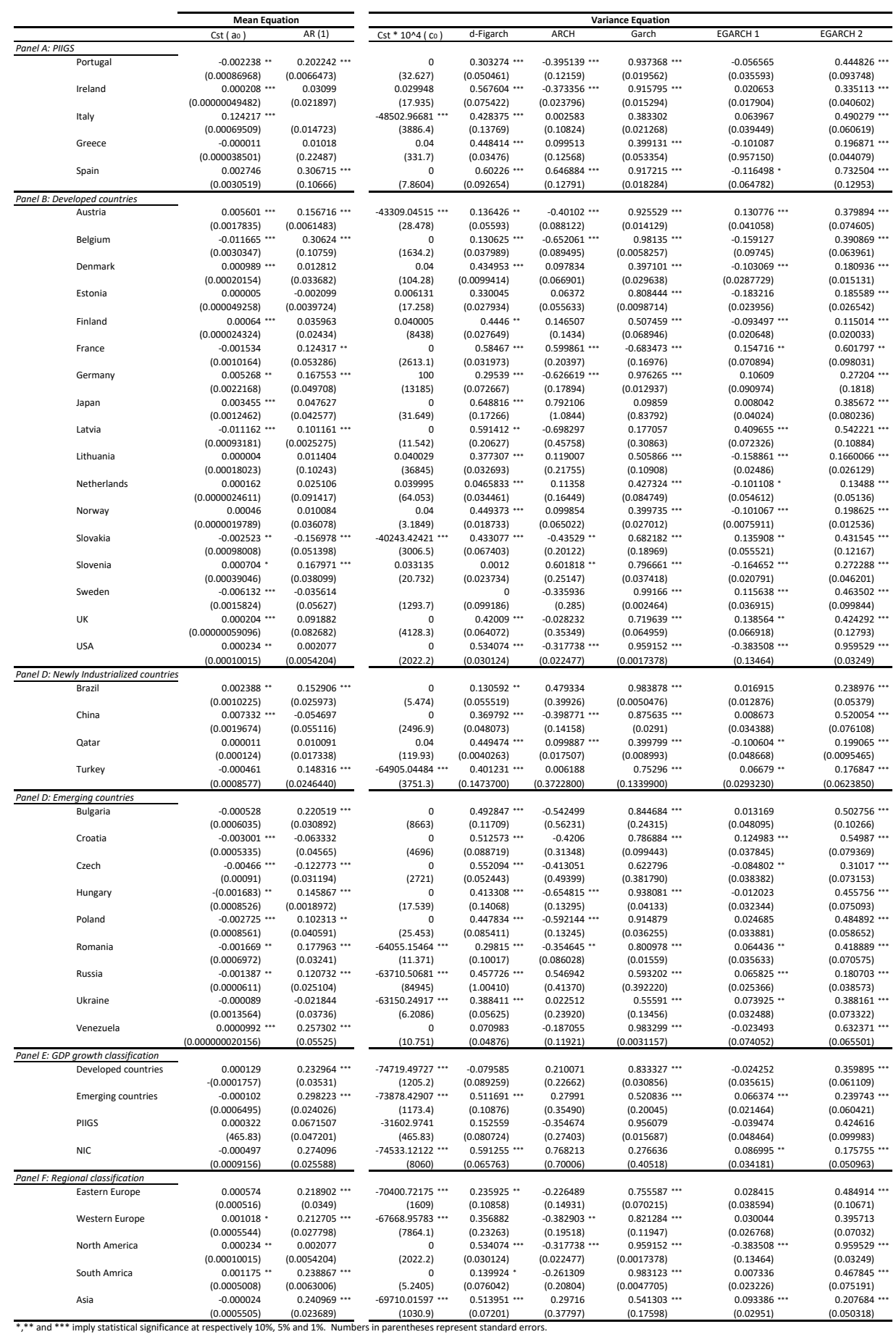


Table 5: The bivariate AR(1)-FIEGARCH estimation results

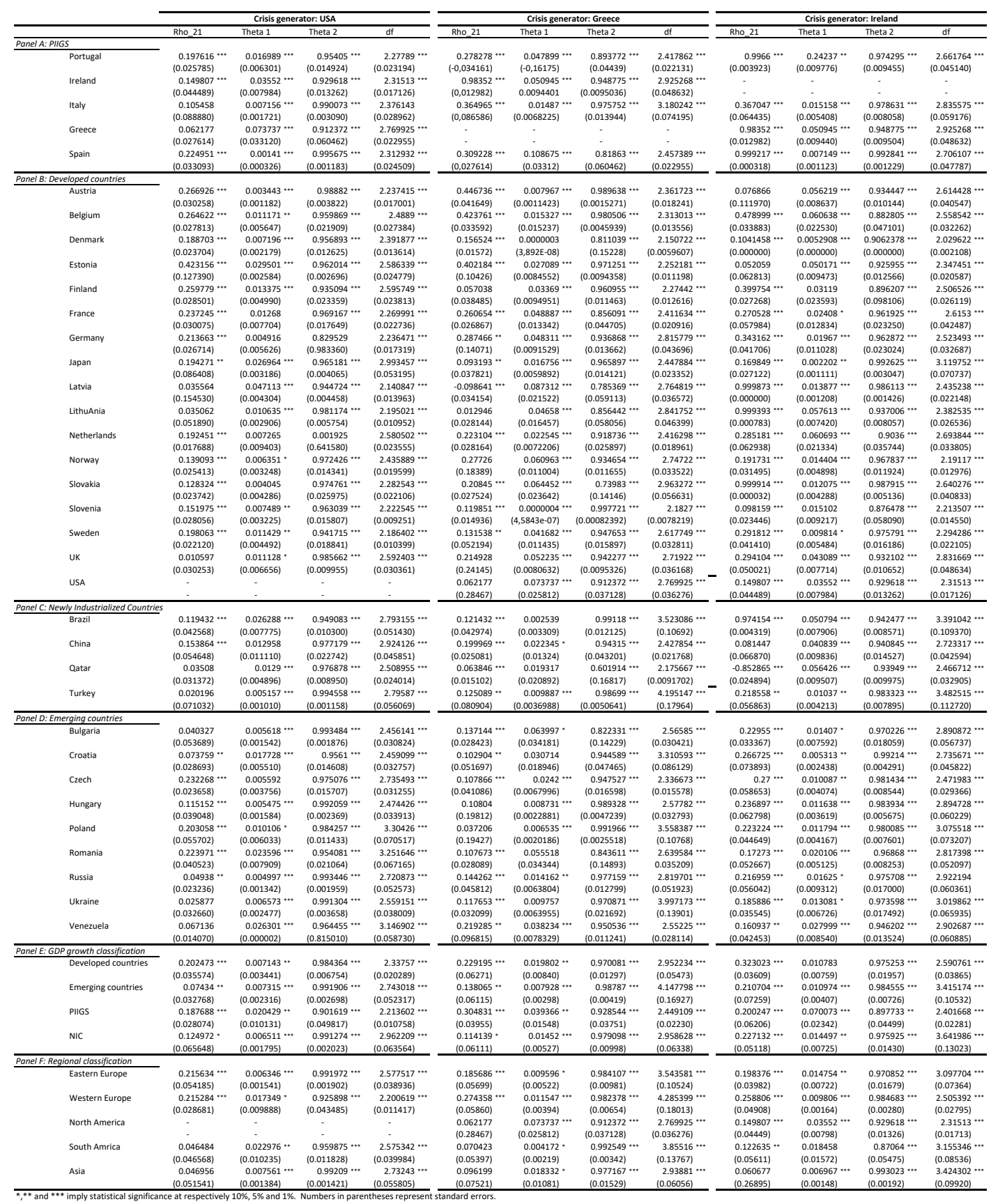


Table 6: Regression results of DCC series (AR(1)-FIEGARCH(1,d,1)-DCC model)

\begin{tabular}{|c|c|c|c|c|c|c|c|c|c|}
\hline & \multicolumn{3}{|c|}{$\begin{array}{l}\text { Crisis generator: USA } \\
\end{array}$} & & Crisis generator: Grec & & & Crisis generator: Irelar & \\
\hline & Alpha 0 (cst) & $\begin{array}{l}\text { Alpha 1(lagged } \\
\text { values) }\end{array}$ & $\begin{array}{c}\text { Beta } 1 \text { (1st } \\
\text { crisis dummy) }\end{array}$ & Alpha 0 (cst) & $\begin{array}{l}\text { Alpha } 1 \text { (lagged } \\
\text { values) }\end{array}$ & $\begin{array}{l}\text { Beta } 2 \text { (2nd } \\
\text { crisis dummy) }\end{array}$ & Alpha 0 (cst) & $\begin{array}{l}\text { Alpha } 1 \text { (lagged } \\
\text { values) }\end{array}$ & $\begin{array}{l}\text { Beta } 2 \text { (2nd } \\
\text { crisis dummy) }\end{array}$ \\
\hline Panel A: PIIGS & & & & & & & & & \\
\hline Portugal & $0.99674^{* * *}$ & $\begin{array}{r}-0.00012 \\
-0.0029\end{array}$ & $\begin{array}{r}0.00079 \\
0.00051\end{array}$ & $0.99472 * \cdots$ & $0.00133^{*}$ & $\begin{array}{r}-0.00031 \\
-100068\end{array}$ & $0.99529 \cdots$ & 0.00019 & 0.00264 \\
\hline Ireland & $\begin{array}{c}(0.00092) \\
0.98781 \ldots *\end{array}$ & $\begin{array}{l}(0.00029) \\
0.00051^{* * *}\end{array}$ & $\begin{array}{l}(0.00054) \\
-0.00061\end{array}$ & $\begin{array}{c}(0.00169) \\
0.99351 \ldots\end{array}$ & $\begin{array}{l}(0.00070) \\
-0.00135 * * *\end{array}$ & $(0.00068) \ldots$ & $(0.00138)$ & $(0.00470)$ & $(0.00962)$ \\
\hline & $(0.00336)$ & $(0.00183)$ & $(0.00217)$ & $(0.00074)$ & $(0.00018)$ & $(0.00037)$ & . & . & : \\
\hline Italy & $0.99654^{k * *}$ & 0.00005 & $0.00129 \cdots$ & $0.99157^{\text {w* }}$ & $0.00204^{* * *}$ & 0.00032 & $0.99266^{w *}$ & $0.00282 \cdots$ & $0.00116 *$ \\
\hline & $(0.00092)$ & $(0.00032)$ & $(0.00044)$ & $(0.00200)$ & $(0.00070)$ & $(0.00069)$ & $(0.00085)$ & $(0.00032)$ & $(0.00050)$ \\
\hline Greece & 0.989958 & $-0.00350586 * *$ & 0.00351811 & - & - & & $0.993513 \cdots$ & $-0.00135345 * * *$ & $0.00266074^{* * *}$ \\
\hline & $(0.003179)$ & $(0.001460)$ & $(0.002050)$ & . & - & . & $(0.000736)$ & $(0.000185)$ & $(0.000366)$ \\
\hline Spain & $\begin{array}{l}1.00061^{\cdots *} \\
(0.00033)\end{array}$ & $\begin{array}{l}-0.00018^{* "} \\
(0.00007)\end{array}$ & $\begin{array}{c}0.00029 \cdots \\
(0.00006)\end{array}$ & $\begin{array}{c}0.99047^{\cdots \cdots} \\
(0.00273)\end{array}$ & $\begin{array}{l}0.00232 \text { "* } \\
(0.00108)\end{array}$ & $\begin{array}{c}0.00049{ }^{* *} \\
(0.00125)\end{array}$ & $\begin{array}{l}0.99733^{* * *} \\
(0.00102)\end{array}$ & $\begin{array}{r}0.00059 \\
(0.00053)\end{array}$ & $0.00118 * *$ \\
\hline Panel B: Developed countries & & & & & & & & & \\
\hline $\begin{array}{r}\text { Austria } \\
\end{array}$ & $1.00061^{* * *}$ & $-0.00028^{* *}$ & $0.00064^{* * *}$ & $0.99498 * \cdots$ & 0.00119 & 0.00033 & $0.99442 \cdots$ & 0.00031 "* & $0.00228 \cdots$ \\
\hline Belgium & $\begin{array}{l}(0.00052) \\
0.9961 \ldots\end{array}$ & $\begin{array}{l}(0.00012) \\
0.00005\end{array}$ & $\begin{array}{r}(0.00014) \\
0.00053\end{array}$ & $(0.00209) \ldots \ldots *$ & $\begin{array}{l}(0.00094) \\
0.0144, \ldots \ldots\end{array}$ & $(0.00118)$ & $(0.00058) \ldots$ & $(0.00016)$ & $(0.00028)$ \\
\hline Belgum & $\begin{array}{c}0.99861 \\
(0.00135)\end{array}$ & $\begin{array}{r}0.00005 \\
(0.00031)\end{array}$ & $\begin{array}{r}0.00053 \\
(0.00040)\end{array}$ & $\begin{array}{l}0.979710^{* *} \\
(0.00410)\end{array}$ & $\begin{array}{l}0.011444^{* * *} \\
(0.00245)\end{array}$ & $\begin{array}{r}-0.00281 \\
(0.00213)\end{array}$ & $\begin{array}{l}0.98390 \cdots \\
(0.00370)\end{array}$ & $\begin{array}{l}0.00608 \text { "* } \\
(0.00608)\end{array}$ & $\begin{array}{c}0.004866^{* *} \\
(0.00486)\end{array}$ \\
\hline Denmark & $1.00010^{* * *}$ & -0.00015 & $0.00059 *$ & $0.98323^{\cdots \cdots}$ & $-0.00519^{* *}$ & $0.00695=$ & $0.99655^{\cdots *}$ & 0.00023 & $0.00141^{*}$ \\
\hline & $(0.00110)$ & $(0.00019)$ & $(0.00025)$ & $(0.00402)$ & $(0.00235)$ & $(0.00380)$ & $(0.00136)$ & $(0.00058)$ & $(0.00083)$ \\
\hline Estonia & $0.99757^{\cdots *}$ & $0.00032 \cdots$ & $-0.00019 \cdots$ & $0.99870^{\cdots \cdots}$ & -0.00011 & $0.00043 *$ & $0.99133^{\cdots *}$ & -0.00115 & 0.00125 \\
\hline & $(0.00006)$ & $(0.00002)$ & $(0.00003)$ & $(0.00071)$ & $(0.00020)$ & $(0.000$ & $(0.00288)$ & & $(0.00163)$ \\
\hline Finland & $0.99799^{* * *}$ & 0.00018 & 0.00066 & $0.99289^{\cdots \cdots}$ & 0.0 & 0.0 & & & \\
\hline & $(0.00176)$ & $(0.00040)$ & $(0.00047)$ & $(0.00290)$ & $(0.00053)$ & $(0.00094)$ & $(0.00505)$ & & $(0.00086)$ \\
\hline France & $0.99828^{* * *}$ & -0.00001 & 0.00068 & $0.96880 \cdots$ & $0.00562^{* * *}$ & 0.00238 "* & $0.98195 \ldots$ & $0.00452^{* * *}$ & $0.00199^{\circ}$ \\
\hline & $(0.00158)$ & $(0.00034)$ & $(0.00050)$ & $(0.00551)$ & $(0.00136)$ & $(0.00162)$ & $(0.00410)$ & $(0.00116)$ & $(0.00113)$ \\
\hline Germany & $0.98861 \ldots *$ & $0.00278^{\cdots *}$ & -0.00015 & $0.97759^{\cdots \cdots}$ & $0.00340^{* *}$ & 0.00205 "* & 0.99676 " & 0.00069 & 0.00091 . \\
\hline & $(0.00344)$ & $(0.00091)$ & $(0.00058)$ & $(0.00471)$ & $(0.00105)$ & $(0.00141)$ & $(0.00149)$ & $(0.00042)$ & $(0.00047)$ \\
\hline Japan & $\begin{array}{l}0.99641^{* * * *} \\
(0.00180)\end{array}$ & $\begin{array}{r}-0.00029 \\
0.00047)\end{array}$ & 0.00122 & $0.991499^{* * *}$ & $0.00128^{* *}$ & -0.00029 & $0.99820^{* \cdots *}$ & 0.00030 & 0.00008 \\
\hline Latvia & $\begin{array}{c}(0.00180) \\
0.99578 \ldots\end{array}$ & $\begin{array}{l}(0.00047) \\
0.00183\end{array}$ * & $\begin{array}{l}(0.000099) \\
-0.00067\end{array}$ & $\begin{array}{c}(0.002909) \\
0.95361 \cdots\end{array}$ & $\begin{array}{l}(0.00053) \\
-0.01057\end{array}$ & $\begin{array}{l}(0.000566) \\
0.00638 *\end{array}$ & $\begin{array}{c}(0.001311) \\
0.99719 \cdots\end{array}$ & $\begin{array}{l}(0.00025) \\
0.00013\end{array}$ & $\begin{array}{l}(0.00017) \\
0.00163 * *\end{array}$ \\
\hline & $(0.00229)$ & $(0.00100)$ & $(0.00170)$ & $(0.00677)$ & $(0.00213)$ & $(0.00275)$ & $(0.00112)$ & $(0.00053)$ & $(0.00067)$ \\
\hline Lithuania & $1.00093^{n * *}$ & 0.00005 & $-0.00119 \cdots$ & $0.97047^{\cdots \cdots}$ & $-0.00259^{* * *}$ & 0.00 & 0.99 & 0033 & $0.00027^{\circ}$ \\
\hline & $(0.00106)$ & $(0.00027)$ & $(0.00044)$ & $(0.00548)$ & $(0.00$ & & & & $(0.00016)$ \\
\hline Netherlands & $0.95082^{\cdots *}$ & & -0.00852 & & & & & & 0.00633 . \\
\hline & $(0.00685)$ & $(0.00463)$ & $(0.00467)$ & $(0.00469)$ & $(0.00261)$ & $(0.00423)$ & $(0.00412)$ & $(0.00183)$ & $(0.00362)$ \\
\hline Norway & $1.00093^{* \cdots *}$ & $-0.00022^{*}$ & $0.00076 \cdots$ & $0.98481^{* * *}$ & $0.006211^{* * *}$ & $\begin{array}{l}-0.00278 \\
-0.0277\end{array}$ & $0.98484^{* * *}$ & 0.00240 " & 0.00119 ** \\
\hline & $(0.00082)$ & $(0.00012)$ & $(0.00024)$ & $(0.00390)$ & $(0.00208)$ & $(0.00237)$ & $(0.00376)$ & $(0.00064)$ & $(0.00053)$ \\
\hline Slovakia & $0.99745^{\cdots *}$ & 0.00017 & 0.00036 * & $0.94072 \ldots$ & 0.00223 & 0.00386 & $0.99393 \ldots$ & $0.00108^{\cdots *}$ & $0.01046 \cdots$ \\
\hline & $(0.00177)$ & $(0.00020)$ & $(0.00016)$ & $(0.00758)$ & $(0.00165)$ & $(0.00290)$ & $(0.00114)$ & $(0.00039)$ & $(0.00038)$ \\
\hline Slovenia & $\begin{array}{l}1.00004^{* * *} \\
(0.00086)\end{array}$ & $-0.00144 \cdots$ & $0.00418 \cdots$ & $0.94740 \cdots$ & $0.02824^{* * *}$ & -0.00721 " & $0.97111 \ldots$ & $-0.00742^{* * *}$ & $0.01250 \cdots$ \\
\hline Sweden & $\begin{array}{c}(0.000886) \\
0.99829\end{array}$ & $\begin{array}{r}\left(\begin{array}{l}(0.00050) \\
0.00011\end{array}\right. \\
0\end{array}$ & $\begin{array}{l}(0.00116) \\
0.00053\end{array}$ & $\begin{array}{r}(0.00716) \\
0.98194 * * *\end{array}$ & $\begin{array}{c}(0.00426) \\
0.00172^{*}\end{array}$ & $\begin{array}{r}(0.000341) \\
0.00268\end{array}$ & $\begin{array}{c}(0.004993) \\
0.99417 \\
\cdots\end{array}$ & $\begin{array}{l}(0.002626) \\
-0.00022\end{array}$ & $\begin{array}{r}(0.00474) \\
0.00240\end{array}$ \\
\hline & $(0.00159)$ & $(0.00030)$ & $(0.00041)$ & $(0.00436)$ & $(0.00090)$ & $(0.00163)$ & $(0.00055)$ & $(0.00013)$ & $(0.00027)$ \\
\hline U.K. & $0.99976^{w *}$ & $-0.00057^{\cdots * *}$ & $0.00123 \ldots$ & $0.98328 * * *$ & $0.00759^{\cdots \cdots}$ & -0.00333 & $0.98875^{\cdots \cdots}$ & $0.00405 \cdots$ & 0.00048 \\
\hline & $(0.00031)$ & $(0.00012)$ & $(0.00025)$ & 4) & (200708) & & & & $(0.00048)$ \\
\hline USA & & - & & $0.98627^{\text {w* }}$ & $-0.00557^{\cdots *}$ & 0.00622 * & $0.98358^{* \cdots}$ & $0.00299 *$ & 0.00278 \\
\hline & & & & $(0.00323)$ & $(0.00100)$ & $(0.00160)$ & $(0.00349)$ & $(0.00138)$ & $(0.00244)$ \\
\hline Panel C: Newly Industrialized Co & ountries & & & & & & & & \\
\hline $\begin{array}{l}\text { Brazil } \\
\end{array}$ & $\begin{array}{c}0.90773^{\cdots *} \\
(0.00925)\end{array}$ & $\begin{array}{l}0.02013^{* * * *} \\
(0.00446)\end{array}$ & $\begin{array}{c}-0.014977^{*} \\
(0.00852)\end{array}$ & $\begin{array}{l}0.99206 \text { "* } \\
(0.00062)\end{array}$ & $\begin{array}{c}0.00035 \text { w" } \\
(0.00011)\end{array}$ & $\begin{array}{l}0.00152 \cdots * \\
(0.00016)\end{array}$ & $0.99786 \cdots$ & $\begin{array}{r}0.00011 \\
(0.00033)\end{array}$ & $0.00066^{*}$ \\
\hline China & $\begin{array}{l}(0.00995) \ldots \\
0.99869 \cdots\end{array}$ & $\begin{array}{l}(0.00446) \\
-0.00025\end{array}$ & $\begin{array}{r}(0.00852) \\
0.00064\end{array}$ & $\begin{array}{r}(0.00062) \ldots \\
0.99818\end{array}$ & $\begin{array}{c}(0.000111) \ldots \\
0.00034\end{array}$ & $\begin{array}{l}(0.000016) \\
0.00000 \cdots\end{array}$ & $\begin{array}{c}(0.00073) \\
0.99828 \cdots\end{array}$ & $\begin{array}{r}(0.000333) \\
0.00073 *\end{array}$ & $\begin{array}{l}(0.00037) \\
-0.00099\end{array}$ \\
\hline & $(0.00119)$ & $(0.00023)$ & $(0.00049)$ & $(0.00068)$ & $(0.00013)$ & $(3,787 \mathrm{E}-9)$ & $(0.00068)$ & $(0.00029)$ & $(0.0005344)$ \\
\hline Qatar & $0.99936 \ldots$ & -0.00009 & 0.00025 . & $1.00069 \cdots$ & $0.00018^{* * *}$ & $-0.00023 \approx * *$ & $0.99559 \cdots$ & -0.00133 & 0.00157 \\
\hline & $(0.00085)$ & $(0.00011)$ & $(0.00015)$ & $(0.00011)$ & $(0.00001)$ & $(0.00$ & & & $(0.00152)$ \\
\hline Turkey & $0.99999+\cdots$ & 0.00001 & $0.00037^{\circ}$ & $0.99584^{\prime \cdots}$ & & & 0.99 & & $880 * *$ \\
\hline & $(0.00093)$ & $(0.00017)$ & $(0.00022)$ & $(0.00214)$ & $(0.00023)$ & $(0.00042)$ & $(0.00141)$ & $\begin{array}{l}(0.00034) \\
(0.03\end{array}$ & $(0.00032)$ \\
\hline Panel D: Emerging countries & & & & & & & & & \\
\hline Bulgaria & $0.99949^{* * *}$ & 0.00003 & 0.00033 & $0.99027^{\cdots *}$ & $-0.00070^{*}$ & $0.00214 \cdots$ & $0.98826^{\cdots *}$ & $0.00222 \cdots$ & $0.00137 * *$ \\
\hline & $(0.00099)$ & $(0.00017)$ & $(0.00022)$ & $(0.00186)$ & $(0.00039)$ & (0.00076) & $(0.003$ & $(0.00071)$ & $(0.00069)$ \\
\hline Croatia & $0.99294^{\cdots *}$ & 0.00125 "* & 0.00056 & $0.98812^{\cdots}$ & 0.00013 & 0.001 & 0.993 & $0.00167 \cdots$ & 0.00041 \\
\hline & $(0.00184)$ & $(0.00055)^{* *}$ & $(0.00064)$ & $(0.00351)$ & $(0.00059)$ & $(0.00$ & $(0.00$ & & $(0.00044)$ \\
\hline Czech & & $0.00276^{\cdots *}$ & -0.00021 & & & & & & \\
\hline & $(0.00$ & $(0.00$ & $(0.00035)$ & & & & & & \\
\hline Hungary & 0.99 & -0.0 & 0.00035 & $0.98766^{\prime *}$ & & & & & \\
\hline & $(0.00133)$ & 10.00 & $(0.00024)$ & & & & & & \\
\hline Poland & $0.99710^{* * *}$ & 0.00041 & 0.00039 & $0.98863^{\cdots \cdots}$ & $0.00094 *$ & $0.00160 *$ & $0.99164 \cdots$ & $0.00147^{* * *}$ & $0.00137 * *$ \\
\hline & $(0.00205)$ & $(0.00045)$ & $(0.00039)$ & $(0.00205)$ & $(0.00046)$ & $(0.00074)$ & $(0.00165)$ & $(0.00048)$ & $(0.00059)$ \\
\hline Romania & $0.98484^{* * *}$ & $0.00285^{* * *}$ & 0.00073 & $0.98767^{\cdots *}$ & -0.00028 & $0.00250 \cdots *$ & $0.99191 \ldots$ & $0.00122 *$ & $0.00157 \cdots$ \\
\hline & $(0.00399)$ & $(0.00090)$ & $(0.00088)$ & $(0.00216)$ & $(0.00044)$ & $(0.00088)$ & $(0.00162)$ & $(0.00048)$ & $(0.00060)$ \\
\hline Russia & $0.99966^{* * *}$ & 0.00001 & $0.00038^{*}$ & $0.99152^{* \cdots}$ & -0.00002 & $0.00171 *$ & $0.99252^{\cdots *}$ & $0.00093 \cdots$ & $0.00152 \cdots$ \\
\hline & & $\begin{array}{r}(0.00017) \\
0.00006\end{array}$ & $(0.00020)$ & & & & 0.001 & & \\
\hline Ukraine & & 0.00006 & 0.00028 * & $0.98720^{* *}$ & $0.00117^{\cdots \cdots}$ & $0.00065^{*}$ & 0.998 & 0.00023 & $0.00032 *$ \\
\hline & $(0.00073)$ & $(0.00011)$ & $(0.00015)$ & $(0.00365)$ & $(0.00038)$ & $(0.00035)$ & $(0.00$ & $(0.000$ & $(0.00017)$ \\
\hline Venezuela & & & 0.00028 & & & & & & \\
\hline & $(0.02009)$ & $(0.00155)$ & 7,962 E-12) & .000306) & $(0.00104)$ & $(0.00188)$ & & $(0.00067)$ & $(0.00049)$ \\
\hline Panel E: GDP growth classificati & & & & & & & & & \\
\hline Developed countries & $\begin{array}{r}0.993928 \cdots \\
(0.000551) \cdots\end{array}$ & $\begin{array}{r}0.00134652 \cdots * \\
(0.000192) \cdots *\end{array}$ & $\begin{array}{r}0.000181317 \\
(0.000183)\end{array}$ & $\begin{array}{c}0.986878 \cdots * \\
(0.003252)\end{array}$ & $\begin{array}{r}0.00128065 \\
(0.000960)\end{array}$ & $\begin{array}{c}0.00339812 * * \\
(0.001702)\end{array}$ & $\begin{array}{c}0.993665 \cdots \\
(0.002240)\end{array}$ & $\begin{array}{l}0.00170437 * * \\
(0.000684)\end{array}$ & $\begin{array}{l}0.00105162, * \\
(0.000493)\end{array}$ \\
\hline Emerging countries & $0.998976 \cdots$ & 0.000037946 & 0.000559745 " & $0.993966^{\cdots} \cdots$ & $0.000532341^{*}$ & 0.000741356 & $0.993501 \cdots$ & $0.0012071^{*}$ & $0.00118778 *$ \\
\hline & & & & $(0.002665)$ & & & & & \\
\hline PIIGS & $\begin{array}{r}0.992771 \ldots * \\
(0.002459) \cdots \cdots\end{array}$ & $\begin{array}{c}-0.001704588^{*} \\
(0.001031)^{*}\end{array}$ & $\begin{array}{r}0.00129535 \\
(0.001724)\end{array}$ & $\begin{array}{c}0.948225 \cdots \\
(0.007099)\end{array}$ & $\begin{array}{l}0.0143851 \ldots \\
(0.002434)\end{array}$ & $\begin{array}{l}0.00143508 \\
(0.002560)\end{array}$ & $\begin{array}{c}0.985986 \cdots \\
(0.003812)\end{array}$ & $\begin{array}{r}-0.000986117 \\
(0.001230)\end{array}$ & $\begin{array}{l}0.00527848 * * \\
(0.002526)\end{array}$ \\
\hline NIC & $0.998288^{\cdots *}$ & 0.000170593 & 0.000255084 & $0.993664 \ldots$ & 0.000450148 & 0.000779645 & $0.990323 \ldots$ & $0.002057 \cdots$ & $0.00142821 *$ \\
\hline & $(0.001543)^{n * *}$ & $(0.000279)$ & $(0.000355)$ & $(0.002784)$ & $(0.000283)$ & 0624) & $(0.002863)$ & $(0.000728)$ & $(0.000697)$ \\
\hline Panel F: Regional classification & & & & & & & & & \\
\hline & $0.992427 * * *$ & $0.000607887 * *$ & $0.000865968 * *$ & $0.988593 * * *$ & $0.00110931 * *$ & $0.00182212 * * *$ & $0.985873 * * *$ & $0.00289836^{* * *}$ & $0.00180322 * *$ \\
\hline Western Europe & $\begin{array}{l}(0.0011119) \\
0.998808 \cdots\end{array}$ & 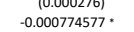 & $\begin{array}{l}(0.000476405 * \\
0 .\end{array}$ & $\begin{array}{l}(0.0009888) \\
0.990302 \cdots\end{array}$ & $\begin{array}{l}(0.0000445) \\
0.00217033 \cdots\end{array}$ & $\begin{array}{l}\left(\begin{array}{l}0.0000005) \\
0.00093823\end{array}\right. \\
-\end{array}$ & $\begin{array}{l}(0.003556) \\
0.99516 \cdots\end{array}$ & $\begin{array}{r}(0.0008875) \ldots \\
-0.00055844 \cdots\end{array}$ & $\begin{array}{l}(0.000831) \ldots \\
0.00264202 \cdots\end{array}$ \\
\hline & $(0.001485)$ & $(0.000408)$ & $(0.000822)$ & $(0.002167)^{\cdots \cdots *}$ & $(0.000714)^{\cdots \cdots}$ & $(0.000739)$ & $(0.000634)$ & $(0.000161)$ & $(0.000365)$ \\
\hline North America . & & & & $0.986267 \ldots *$ & $-0.00556734 \cdots *$ & 0.00621885 * & $0.983576 \ldots$ & $0.00298668 *$ & 0.00277878 \\
\hline & & & & $(0.003229)$ & $(0.001002)$ & $(0.001597)$ & $(0.003485)$ & $(0.001378)$ & $(0.002441)$ \\
\hline South America & $0.95529 \cdots$ & $0.00976811 \cdots *$ & $-0.00844867^{\circ}$ & $0.991993 \cdots$ & $0.000391219 \cdots$ & $0.00136732 \cdots$ & $0.98874 \cdots$ & $0.00273529 * *$ & 0.000674256 \\
\hline & & & & & $(0.000122)$ & $(0.000184)$ & $(0.00304 \pi)$ & $(0.001351)$ & $(0.001742)$ \\
\hline Asia & $\begin{array}{c}0.999795 * * * \\
(0.001054)\end{array}$ & $\begin{array}{r}-0.000100236 \\
(0.000232)\end{array}$ & $\begin{array}{c}0.000721909 * * \\
(0.000306)\end{array}$ & $\begin{array}{l}0.988204 * * * \\
(0.002006)\end{array}$ & $\begin{array}{r}0.000501309 \\
(0.000429)\end{array}$ & $\begin{array}{l}0.00194118^{* * *} \\
(0.000726)\end{array}$ & $\begin{array}{l}0.98687 * * * \\
(0.003384)\end{array}$ & $0.00315004 \cdots$ & $0.0016882 * *$ \\
\hline & & & & (10.0002000) & $\frac{(0.000429)}{20 \text { tand }}$ & $(0.0000 / 26)$ & & & 1.000817 \\
\hline
\end{tabular}


after the Lehman brothers bankruptcy - investors flee unsafe investments and reduce their exposure to USA stock market - considered as more and more risky - by selling simultaneously their financial assets and preferring liquidity that is becoming increasingly scarce. This sell-off leads, accordingly, to a global fall in international stock markets' values and drives, thus, to the occurrence of contagion effects notably in the sovereign CDS markets.

Third, the USA have always favored the process of globalization. The expansion of economic integration on a global scale has led the USA to develop an external demand, to accumulate a consequent volume of transactions and exchanges with the outside world and to extend their relative dependence on foreign markets ${ }^{22}$. These facts can explain the repercussions of the subprime crisis on several foreign countries - belonging to different regions and different categories of economic growth - and its transformation into a global financial crisis. These explanations are strongly coherent with the DCC pattern represented in figure 3.1.

Furthermore, the number of countries affected by contagion effects is more important during the second crisis compared to the first crisis periods. In fact, these findings suggest that the financial crisis played a role in the transfer of credit risk from banks to the Sovereign States, even if the PIIGS and three other main European countries survived to the credit crunch and the Lehman Brothers failure. Then, the cost of the repurchase of the private sector debts by the sovereign governments increased the sovereign credit risk and so caused new waves of contagion in November, 2009. Finally, the worsening of the Greece situation in MarsApril, 2010 ( $4^{\text {th }}$ period) made financial markets, generally, even more nervous so favoring the transmission of financial distress through almost all the studied countries. Correlations increased in a significant way between Greece and low economy growth countries, between Greece and 10 developed countries (namely France and Germany, Netherlands), between Greece and emerging countries (except for Croatia and Venezuela) and between Greece and all newly industrialized countries.

Unlike some previous research, we don't believe that contagion phenomenon detected during the global financial crisis among the sample countries is attributed to fundamental reasons since they present very heterogeneous trade and financial characteristics: our countries' economic profile differs from one country to another. Developed countries - which are the most technically advanced, base their sustainable development on technological progress, while the integration of emerging countries into the world economy is justified by the important volume of their exportation (commodity products exports for Russia or Bulgaria for example and manufactured products exports for Croatia or Hungary...). In the another side,

\footnotetext{
${ }^{22}$ According to the OECD report (2016), USA external demand in terms of exports and imports exceeded 12 million dollar.
} 
newly industrialized countries (especially China and Turkey) are characterized by a high level of economic openness which represents $33 \%$ in China and $12 \%$ in USA according to the latest WTO's report. These countries also present a high external dependence since a significant part of the local investments are made by multinational firms. Thus, the principal finding here is that the contagion evidence based on our econometric approaches is not related to a common trade profiles.

\section{Conclusion}

The aim of this paper is to analyze sovereign risk as well as the financial contagion effect in CDS markets of countries with low economic growth (PIIGS), developed countries, emerging countries and newly industrialized countries. To detect the occurrence of long-term contagion phenomenon, analyses have been performed over a long period going from January, 2006 to April, 2014. The studied period is long enough to cover both the global financial crisis and the European debt crisis.

Since contagion is characterized by an increase of the correlations between countries, an analysis of sovereign CDS spreads' conditional correlations of different countries was made using both EWMA and AR(1)-FIEGARCH(1,d,1)DCC approaches. The first approach is used to compare our results with those of the literature, while the second one takes account of more CDS market's specifications such as long memory behavior, volatility clustering, information asymmetries and the speed that information is reflected in CDS prices. An econometric study of these correlations is made over several sub-periods - during a quiet phase, after the credit crunch and during the European sovereign debts crisis - in order to detect any significant level changes.

We find that sovereign CDS markets experienced several contagion phases. Conditional correlations increased considerably during both crisis periods confirming a insulating behavior of CDS markets during the quiet period. Most of countries around the word recouple during the GFC, particularly after the credit crunch, and during the Sovereign crisis which confirms the role played by crises in the transmission of financial distress through countries. That said, the increase in cross-markets linkages after the occurrence of a financial shocks does not seem to due to common characteristics since our sample countries present financial and economic profiles very different.

All countries were affected by the financial contagion phenomenon in different levels: countries with low economic growth strongly reacted to financial shocks, whereas developed countries and newly industrialized countries were affected in lesser intensity. Similar countries responses to financial shocks - arisen on the markets of CDS - underline the importance of the credit markets international integration. We also show that financial distresses propagation between markets 
does not concern only countries of the same geographical area: Some of Asian countries were touched by the European debt crisis which confirms the transmission of the financial shocks from Europe to Asia.

Our findings proved that the number of significant interdependences between different pairs of countries increased during crises phases compared to quiet period. Results show that there is actually a crisis transmission through CDS markets during the credit crunch. The contagion phenomenon is stressed with the start of the European Debt crisis. Thus we think, undoubtedly, that the credit crisis of 2007-2009 played the main role in the spread of the crisis through CDS markets and in the transmission of the sovereign credit risk.

These findings discredit the appropriate use of portfolio diversification since counterparty risk increases considerably in this case. Traders should not simultaneously invest in several markets that are vulnerable and subject to contagion effects. In fact, since most of sovereign CDS markets are highly correlated and fluctuate at the same direction, a shift in investors' appetite for risk in a single country can imply a decease in the whole portfolio's returns. On the other hand, these results help policy makers in the eventual decision-making especially when it comes to protect countries from future crises. First, Politicians should put in place an insulating procedures for countries prone to contagion effects, namely low economic growth countries, NIC and emerging countries. Second, a long period of high risk taking in a particular market should be interpreted as a signal of financial bubble creation and consequent measures must be taken to stabilize the crisis-generating country. Joint decisions between countries such as increasing liquidity and/or reducing the interest rates could be good solutions to reduce the financial crash occurrence's probability and thus the crisis transmission across countries.

\section{References}

Acharya, V., Drechsler, I. and Schnabl, P. (2014), 'A pyrrhic victory? bank bailouts and sovereign credit risk', The Journal of Finance 69(6), 26892739.

Alter, A. and Schüler, Y. S. (2012), 'Credit spread interdependencies of european states and banks during the financial crisis', Journal of Banking \& Finance 36(12), 3444-3468.

Baillie, R. T., Bollerslev, T. and Mikkelsen, H. O. (1996), 'Fractionally integrated generalized autoregressive conditional heteroskedasticity', Journal of econometrics 74(1), 3-30. 
Blinder, A. S. (2013), After the music stopped: The financial crisis, the response, and the work ahead, Penguin Group USA.

Bollerslev, T. and Mikkelsen, H. O. (1996), 'Modeling and pricing long memory in stock market volatility', Journal of econometrics 73(1), 151-184.

Borio, C. E. (2008), 'The financial turmoil of 2007-?: a preliminary assessment and some policy considerations'.

Broto, C. and Perez-Quiros, G. (2015), 'Disentangling contagion among sovereign cds spreads during the european debt crisis', Journal of Empirical Finance 32, 165-179.

Caporale, G. M., Cipollini, A. and Spagnolo, N. (2005), 'Testing for contagion: a conditional correlation analysis', Journal of Empirical Finance 12(3), 476489.

Caramazza, F., Ricci, L. and Salgado, R. (2004), 'International financial contagion in currency crises', Journal of International Money and Finance 23(1), 5170 .

Chiang, T. C., Jeon, B. N. and Li, H. (2007), 'Dynamic correlation analysis of financial contagion: Evidence from asian markets', Journal of International Money and Finance 26(7), 1206-1228.

Christensen, B. J., Nielsen, M. Ø. and Zhu, J. (2010), 'Long memory in stock market volatility and the volatility-in-mean effect: the fiegarch-m model', Journal of Empirical Finance 17(3), 460-470.

Conrad, C., Karanasos, M. and Zeng, N. (2011), 'Multivariate fractionally integrated aparch modeling of stock market volatility: A multi-country study', Journal of Empirical Finance 18(1), 147-159.

Coudert, V. and Gex, M. (2010), 'Contagion inside the credit default swaps market: The case of the gm and ford crisis in 2005', Journal of International Financial Markets, Institutions and Money 20(2), 109-134.

D’Apice, V. and Ferri, G. (2010), Financial instability: toolkit for interpreting boom and bust cycles, Springer.

de Castro Miranda, R. C., Tabak, B. M., Junior, M. M. et al. (2012), Contagion in cds, banking and equity markets, Technical report. 
Dimitriou, D., Kenourgios, D. and Simos, T. (2013), 'Global financial crisis and emerging stock market contagion: A multivariate fiaparch-dcc approach', International Review of Financial Analysis 30, 46-56.

Dron, D. and Pillet, D. (2016), Prix bas du pétrole et crise financière internationale: un couple à hauts risques, in 'Annales des Mines-Responsabilité et environnement', number 3, FFE, pp. 87-96.

Ejsing, J. and Lemke, W. (2011), 'The janus-headed salvation: Sovereign and bank credit risk premia during 2008-2009', Economics Letters 110(1), 2831 .

Engle, R. (2002), 'Dynamic conditional correlation: A simple class of multivariate generalized autoregressive conditional heteroskedasticity models', Journal of Business \& Economic Statistics 20(3), 339-350.

Engle, R. and Kelly, B. (2012), 'Dynamic equicorrelation', Journal of Business \& Economic Statistics 30(2), 212-228.

Evans-Pritchard, A. (2010), 'With the us trapped in depression, this really is strasting to feel like 1932'.

Fantazzini, D. (2011), 'Fractionally integrated models for volatility: A reviewempirical appendix: Some examples with $\mathrm{r}$ interfaced with the ox package $\mathrm{g} @$ rch', Available at SSRN 1752095.

Ferreira, M. A. and Lopez, J. A. (2005), 'Evaluating interest rate covariance models within a value-at-risk framework', Journal of Financial Econometrics 3(1), 126-168.

Forbes, K. J. and Chinn, M. D. (2004), 'A decomposition of global linkages in financial markets over time', Review of Economics and Statistics 86(3), 705722.

Forbes, K. J. and Rigobon, R. (2002), 'No contagion, only interdependence: measuring stock market comovements', The journal of Finance 57(5), 22232261.

Geweke, J. and Porter-Hudak, S. (1983), 'The estimation and application of long memory time series models', Journal of time series analysis 4(4), 221-238.

Goudarzi, H. and Ramanarayanan, C. (2010), 'Modeling and estimation of volatility in the indian stock market', International Journal of Business and Management 5(2), 85. 
Grammatikos, T. and Vermeulen, R. (2012), 'Transmission of the financial and sovereign debt crises to the emu: Stock prices, cds spreads and exchange rates', Journal of International Money and Finance 31(3), 517-533.

Günay, S., Shi, Y. et al. (2016), 'Long-memory in volatilities of cds spreads: Evidences from the emerging markets', Journal for Economic Forecasting (1), 122-137.

Jarrow, R. A. and Yu, F. (2001), 'Counterparty risk and the pricing of defaultable securities', the Journal of Finance 56(5), 1765-1799.

Jorion, P. and Zhang, G. (2007), 'Good and bad credit contagion: Evidence from credit default swaps', Journal of Financial Economics 84(3), 860-883.

Kalbaska, A. and Gatkowski, M. (2012), 'Eurozone sovereign contagion: Evidence from the cds market (2005-2010)', Journal of Economic Behavior and Organization 83(3), 657-673.

Kenourgios, D. and Dimitriou, D. (2015), 'Contagion of the global financial crisis and the real economy: A regional analysis', Economic Modelling 44, 283293.

Kodres, L. E. and Pritsker, M. (2002), 'A rational expectations model of financial contagion', The journal of finance 57(2), 769-799.

Kumar, M. S. and Persaud, A. (2002), 'Pure contagion and investors shifting risk appetite: analytical issues and empirical evidence', International Finance 5(3), 401-436.

Lee, B. S., Paek, M., Ha, Y. and Ko, K. (2015), 'The dynamics of market volatility, market return, and equity fund flow: International evidence', International Review of Economics \& Finance 35, 214-227.

Longstaff, F. A., Pan, J., Pedersen, L. H. and Singleton, K. J. (2011), 'How sovereign is sovereign credit risk?', American Economic Journal: Macroeconomics 3(2), 75-103.

Markose, S. M., Giansante, S., Gatkowski, M. and Shaghaghi, A. R. (2010), ‘Too interconnected to fail: Financial contagion and systemic risk in network model of cds and other credit enhancement obligations of us banks'.

Missio, S. and Watzka, S. (2011), 'Financial contagion and the european debt crisis'. 
Morgan, J. (1996), 'Riskmetrics technical document', 4th ed.J.P Morgan, New York .

Packer, F. and Wooldridge, P. D. (2005), '1. overview: repricing in credit markets', BIS Quarterly Review p. 1.

Pan, J. and Singleton, K. J. (2008), 'Default and recovery implicit in the term structure of sovereign cds spreads', The Journal of Finance 63(5), 23452384.

Pentecôte, J.-S., Poutineau, J.-C., Rondeau, F. et al. (2016), 'Les conséquences de la crise financière sur le commerce intra-européen', Studia Oeconomica Posnaniensia 4(3), 7-30.

Pericoli, M. and Sbracia, M. (2003), 'A primer on financial contagion', Journal of Economic Surveys 17(4), 571-608.

Pisani-Ferry, J., Sapir, A., Wolff, G. B. et al. (2013), EU-IMF assistance to euroarea countries: an early assessment, Vol. 16, Bruegel Brussels.

Pritsker, M. (2001), The channels for financial contagion, in 'International financial contagion', Springer, pp. 67-95.

Rampell, C. (2009), 'Great recession: A brief etymology', New York Times 11, 2009.

Rampell, C. (2010), 'The great recession earns its title', New York Times .

Raza, H., Prasad, G. and Li, Y. (2015), 'Ewma model based shift-detection methods for detecting covariate shifts in non-stationary environments', Pattern Recognition 48(3), 659-669.

Reinhart, C. M. (2010), This time is different chartbook: country histories on debt, default, and financial crises, Technical report, National Bureau of Economic Research.

Reinhart, C. M. and Rogoff, K. S. (2008), This time is different: A panoramic view of eight centuries of financial crises, Technical report, National Bureau of Economic Research.

Robinson, P. M. and Henry, M. (1999), 'Long and short memory conditional heteroskedasticity in estimating the memory parameter of levels', Econometric theory 15(03), 299-336. 
Ruiz, E. and Veiga, H. (2008), 'Modelling long-memory volatilities with leverage effect: A-lmsv versus fiegarch', Computational Statistics \& Data Analysis 52(6), 2846-2862.

Srivastava, S., Lin, H., Premachandra, I. M. and Roberts, H. (2016), 'Global risk spillover and the predictability of sovereign cds spread: International evidence', International Review of Economics \& Finance 41, 371-390.

Surgailis, D. and Viano, M.-C. (2002), 'Long memory properties and covariance structure of the egarch model', ESAIM: Probability and Statistics 6, 311329.

Tse, Y. K. and Tsui, A. K. C. (2002), 'A multivariate generalized autoregressive conditional heteroscedasticity model with time-varying correlations', Journal of Business \& Economic Statistics 20(3), 351-362.

Wang, P. and Moore, T. (2012), 'The integration of the credit default swap markets during the us subprime crisis: Dynamic correlation analysis', Journal of International Financial Markets, Institutions and Money 22(1), 1-15.

Youssef, M. and Belkacem, L. (2015), 'On the impact of oil price fluctuations on stock markets: A multivariate long-memory garch framework'. 